\title{
COMMENTS
}

\section{Certification of EEOC Class Suits Under Rule 23}

Title VII of the Civil Rights Act of $1964,{ }^{1}$ enacted to ensure equality of employment opportunities by eliminating discrimination on the basis of race, color, religion, sex, or national origin, ${ }^{2}$ created the Equal Employment Opportunity Commission (the EEOC). ${ }^{3}$ Initially, the Act provided two methods of enforcing the rights it created: aggrieved individuals might sue under section 706 of the Act ${ }^{4}$ or the Attorney General might sue under section 707 to eliminate a "pattern or practice" of discrimination. ${ }^{5}$ The EEOC's role was to eliminate unlawful employment practices by "informal methods of conference, conciliation, and persuasion." In 1972 Congress radically altered the enforcement scheme of Title VII. ${ }^{7}$ The Equal Employment Opportunity Act of 1972 authorized the EEOC to sue on behalf of individuals under section $706^{8}$ and transferred authority to bring section 707 pattern-or-practice suits from the Attorney General to the EEOC. ${ }^{8}$ Subsequently the EEOC began suing for classwide relief-including monetary relief-under sections 706 and 707 without certification under rule 23 of the Federal Rules of Civil Procedure.10 Title VII, "a statute notable for its expanses of congressional silence,"11 does not indicate whether the EEOC must seek certification as a rule 23 representative in suits for

1 Pub. L. No. 88-352, $\S 701-716,78$ Stat. 253 (current version at 42 U.S.C. $\S \S 2000 \mathrm{a}-$ $2000 \mathrm{~h}$ ) [hereinafter cited without cross-reference as Act of 1964].

2 See Johnson v. REA, 421 U.S. 454, 457 (1975).

${ }^{3}$ Act of 1964, $\S 705$.

1 Id. $\S 706(\mathrm{e})$.

Id. $\$ 707$.

- Id. \& 706(a).

I See Act of 1964, as amended by Equal Employment Opportunity Act of 1972, Pub. L. No. 92-261, 86 Stat. 104 (codified at 42 U.S.C. $\$ 2000 \mathrm{a}-2000 \mathrm{~h}$ (1976)) [hereinafter cited without cross-reference as Act of 1972].

8 Id. $\S 706,42$ U.S.C. $\& 2000 \mathrm{e}-5$ (1976).

- Id. § 707, 42 U.S.C. $\S 2000 \mathrm{e}-6$ (1976).

10 E.g., EEOC v. D.H. Holmes Co., 556 F. 2 d 787 (5th Cir. 1977), cert. denied, 436 U.S. 962 (1978).

" Occidental Life Ins. Co. v. EEOC, 432 U.S. 355, 380 n.4 (1977) (Rehnquist, J., joined by Burger, C.J., dissenting in part). But see United Steel Workers v. Weber, 99 S. Ct. 2721, 2734 (1979) (Burger, C.J., dissenting) ("When Congress enacted Title VII after long study and searching debate, it produced a statute of extraordinary clarity"). 
classwide relief, ${ }^{12}$ and the courts have expressed divergent views on this issue.

All courts allow the EEOC to bring class actions. In patternor-practice suits under section 707 , courts have apparently assumed that the EEOC has inherent authority to seek classwide relief and thus need not be certified as a rule 23 representative. ${ }^{13}$ In section 706 suits, however, the courts have sharply disagreed whether class certification is necessary before a class suit may be brought. Several district courts and the Fifth Circuit have held that, absent rule 23 certification, the EEOC lacks authority to seek classwide relief. ${ }^{14}$ Other district courts and the Ninth Circuit have concluded that the EEOC need not seek class certification..$^{15}$ One court has stated that the EEOC's inability to meet rule 23 prerequisites precludes a class action under section 706 but not under section $707 . \cdot^{16}$. This comment

12 Act of 1972, $\S 706,707,42$ U.S.C. $\$ \S 2000 \mathrm{e}-5,2000 \mathrm{e}-6$ (1976).

13 See, e.g., EEOC v. Akron Nat'l Bank \& Trust Co., 78 F.R.D. 684 (N.D. Ohio 1978); EEOC v. Stroh Brewery Co., 19 Fair Empl. Prac. Cas. 1099 (E.D. Mich. 1979).

1 EEOC v. D.H. Holmes Co., 556 F.2d 787 (5th Cir. 1977), cert. denied, 436 U.S. 962 (1978); EEOC v. Delaware Trust Co., 18 Fair Empl. Prac. Cas. 1521 (D. Del. 1979); EEOC v. Page Eng'r 17 Fair Empl. Prac. Cas. 1638 (N.D. Ill. 1978); EEOC v. Continental Oil Co., No. 74-M-776 (D. Colo. Aug. 12, 1975), aff'd on other grounds, 548 F.2d 884 (10th Cir. 1977). See also EEOC v. Datapoint Corp., 570 F.2d 1264 (5th Cir. 1978). Cf. EEOC v. Akron Nat'l Bank \& Trust Co., 78 F.R.D. 684 (N.D. Ohio 1978) (holding that EEOC could not seek classwide relief in suits under section 706 because it was neither a member of the class nor an adequate representative). Recently, one commentator adopted the postition of those courts that apply rule 23 to EEOC actions. Bumpass, The Application of Rule 23 of the Federal Rules of Civil Procedure to Actions Brought by the Equal Employment Opportunity Commission, 29 Case W.L. Rev. 343 (1979).

is EEOC v. General Tel. Co., 20 Fair Empl. Prac. Cas. 52 (9th Cir. 1979); EEOC v. Stroh Brewery Co., 19 Fair Empl. Prac. Cas. 1099 (E.D. Mich. 1979); EEOC v. Singer Controls Co., 80 F.R.D. 76 (N.D. Ohio 1978); EEOC v. Raymond Metal Prods. Co., 17 Fair Empl. Prac. Cas. 206 (D. Md. 1978); EEOC v. Schlueter Mfg. Co., 17 Fair Empl. Prac. Cas. 53 (E.D. Mo. 1978); EEOC v. Whirlpool Corp., 80 F.R.D. 10 (N.D. Ind. 1978); EEOC v. Pinkerton's, Inc., 14 Fair Empl. Prac. Cas. 1431 (W.D. Pa. 1977); EEOC v. Vinnell-Dravo-Lockheed-Mannix, 417 F. Supp. 575 (E.D. Wash. 1976); EEOC v. CTS of Ashville, Inc., 13 Fair Empl. Prac. Cas. 852 (W.D.N.C. 1976); EEOC v. Rexene Polymers Co., 10 Fair Empl. Prac. Cas. 61 (W.D. Tex. 1975); EEOC v. Lutheran Hosp., 10 Fair Empl. Prac. Cas. 1177 (E.D. Mo. 1974); EEOC v. Mobil Oil Corp., 6 Fair Empl. Prac. Cas. 727 (W.D. Mo. 1973). One commentator has taken this position. Reiter, The Applicability of Rule 23 to EEOC Suits: An Examination of EEOC v. D.H. Holmes Co., 28 Syracuse L. Rev. 741 (1977).

16 EEOC v. Akron Nat'l Bank \& Trust Co., 78 F.R.D. 684, 690-91 (N.D. Ohio 1978). In Akron, the court held that the EEOC was exempt from rule 23 in suits under section 707 but not 706. The EEOC merely amended its complaint to sue on the basis of a newly filed commissioner charge of a pattern 'or practice of discrimination. Interview with John $R$. Sweeney, Trial Attorney, EEOC, Chicago Regional Office of General Counsel, in Chicago (Nov. 16, 1977). This procedure may have some practical impact. Section 706(g) limits back pay recovery to a period beginning two years prior to the filing of the charge. This limitation may not apply to suits under section 707. See B. Schlei \& P. Grossman, EMpLoyment DiscrimINATTON LAW 1239 (1976) ("The two-year maximum limitation on back pay does not by its 
analyzes the applicability of rule 23 to EEOC suits under both sections 706 and 707 and concludes that class certification under rule 23 is mandated by rule 19-and appropriate in terms of the enforcement scheme envisaged by Congress-in any EEOC class action. The comment initially examines the role of the EEOC in enforcing Title VII, then evaluates the availability of rule 23 certification in EEOC suits, the necessity for such certification, and the important consequences of certification for the conduct of equal employment opportunity enforcement.

\section{The Enforcement Provisions}

Since Title VII's enactment in 1964, Congress's thinking on the enforcement of Title VII rights has come full circle. The original bill ${ }^{17}$ outlawing employment discrimination gave primary enforcement responsibility to the EEOC and contained a single enforcement section. ${ }^{18}$ As finally enacted, however, Title VII contained two distinct enforcement provisions, ${ }^{19}$ dividing enforcement responsibilities between the Attorney General ${ }^{20}$ and aggrieved individuals or the EEOC. ${ }^{21}$ In 1972, Congress returned to the original conception and vested primary enforcement responsibility in the EEOC. ${ }^{22}$ But no effort was made to return to a single enforcement provision. The result, according to Senator Harrison Williams, one of the floor leaders of the Equal Employment Act of 1972, has been "redundancy in the law." 23

terms apply to suits by the EEOC or the Attorney General under $\S 707 . ")$. If this limitation does apply to section 707 suits, a suit based on a newly filed commissioner charge will result in a smaller back pay recovery.

${ }^{17}$ H.R. 7152, 88th Cong., 1st Sess. (1963), reported in H.R. REP. No. 914, 88th Cong., 1st Sess. (1963), reprinted in Equal EMPLOYMEnT OPPoRTunity CoMmission, Legislative HisTORY of TtTLes VII AND XI of Crvil Rights Act of 1964, at 2001 (1968) [hereinafter cited as 1964 Legislative HistoRy].

${ }^{18}$ As originally reported, section 706 of H.R. 7152 provided that suits could be brought in district court by the EEOC, or if the EEOC failed to sue, by the person claiming to be aggrieved, provided one of the five commissioners gave the individual written permission. H.R. REP. No. 914, 88th Cong., 1st Sess. 12 (1963), reprinted in 1964 Legislative History, supra note 17 , at 2011-12.

1) Act of 1964, $\S \S 706-707$.

20 Section 707 of the Act of 1964 authorized the Attorney General to sue whenever he had "reasonable cause" to believe the defendant was engaging in a pattern or practice of discrimination. Unlike enforcement by individuals under section 706, such suits were not based on a charge, nor was the administrative voluntary compliance procedure applicable.

${ }^{21}$ Section 706 of the Act of 1964 authorized aggrieved individuals to file a charge with the EEOC. If the EEOC was unable to conciliate the charge, the charging party was authorized to sue in district court, but the EEOC was not.

22 Act of 1972, \$§ 706-707, 42 U.S.C. $\$ \$ 2000 \mathrm{e}-5$ to $2000 \mathrm{e}-6$ (1976).

23118 Cong. REc. 4081 (1972), reprinted in Subcomm. on Labor of the Senate Comm. 


\section{A. Section 706}

The provisions of section 706 are set in motion by filing a charge alleging that an employer has engaged in an unlawful employment practice. ${ }^{24}$ Such a charge may be filed either by or on behalf of an aggrieved individual or by any one of the five EEOC commissioners..$^{25}$ After a charge has been filed, the EEOC must investigate. ${ }^{26}$ Within ten days of the filing of the charge the employer must be given notice that a charge has been filed. ${ }^{27}$ If the Commission finds reasonable cause to believe that the employer is unlawfully discriminating, then the EEOC must attempt to eliminate the discriminatory practice by seeking voluntary compliance with the law. ${ }^{28}$ If, within thirty days of filing the charge, voluntary compliance is not secured, the EEOC is authorized to sue in federal district court for injunctive relief and back pay. ${ }^{29}$ Aggrieved individuals-those on whose behalf the EEOC is authorized to sue ${ }^{30}$-have a statutory right to intervene in the EEOC action. ${ }^{31}$

If the Commission does not conciliate the charge or bring suit within 180 days of the filing of the charge, or if the EEOC dismisses the charge as lacking reasonable cause, it must notify the aggrieved persons of their right to sue..$^{32}$ The aggrieved persons may then bring suit in federal district court within 90 days of notification. ${ }^{33}$ In practice, however, the EEOC does not send notice of the right to sue within 180 days of the filing of the charge if compliance has not been obtained. ${ }^{34}$ Right-to-sue letters are sent only at the request of a

on Labor and Public Welfare, 92nd Cong., 2d Sess., Legislative History of the Equal EMPLOYMENT OPPORTUNITY ACT OF 1972, at 1587 (1972) [hereinafter cited as 1972 LEGISLATTVE HISTORY].

24 Act of $1972, \S 706(\mathrm{~b}), 42$ U.S.C. $\S 2000 \mathrm{e}-5$ (b) (1976).

${ }^{25}$ Id., $\S \S 705(\mathrm{a}), 706(\mathrm{~b}), 42$ U.S.C. $\$ \S 2000 \mathrm{e}-4(\mathrm{a}), 2000 \mathrm{e}-5(\mathrm{~b})$ (1976).

24 Id., $\S 706(\mathrm{~b}), 42$ U.S.C. $\S 2000 \mathrm{e}-5(\mathrm{~b})(1976)$.

${ }^{7}$ Id.

28 Id.

Id., $\S 706(f)(1)$, (f)(3), (g), 42 U.S.C. $\S 2000 \mathrm{e}-5(\mathrm{f})(1)$, (f)(3), (g) (1976).

30 Although for purposes of intervention "aggrieved individuals" is not defined, the phrase apparently refers to persons on whose behalf the EEOC is authorized to sue: the charging party, or the person allegedly aggrieved if the charge was filed "on behalf of an aggrieved individual" or by a commissioner. See Act of $1972, \S 706(f)(1), 42$ U.S.C. $\S 2000 \mathrm{e}-$ 5(f)(1) (1976); EEOC v. General Tel. Co., 20 Fair Empl. Prac. Cas. 52, 60 (9th Cir. 1979) ("a district court might ... order the issuance of an appropriate notice which informs the charging party and members of the class of the pendancy of the action and their statutory right to intervene") (emphasis added).

31 Act of 1972, §706(f)(1), 42 U.S.C. $\$ 2000 \mathrm{e}-5(\mathrm{f})(1)(1976)$.

32 Id.

3s Id.

34 See 29 C.F.R. $\S 1601.25$ (1978) (requires notice only when the Commission determines that further efforts to obtain voluntary compliance would be futile or unproductive). 
charging party or if, after completion of the entire administrative process, the EEOC has decided not to sue. ${ }^{35}$ Courts have consistently upheld this departure from the statute, reasoning that the Commission should be permitted to continue processing a charge beyond the 180-day period if the matter might be resolved without litigation and that private parties, who did not receive timely notice of their right to sue, should not be barred from suit by the EEOC's delay. ${ }^{36}$

\section{B. Section 707}

Prior to the 1972 amendments, section 707 authorized the Attorney General to bring suit whenever he had "reasonable cause to believe that any person or group of persons is engaged in a pattern or practice of" discrimination. ${ }^{37}$ No charge had to be filed, and none of the section 706 procedures applied. ${ }^{38}$ The 1972 amendments, however, assimilated section 707 to section 706 . A charge must now be filed" $^{38}$ and "[a]ll ... actions [under section 707] ... shall be conducted in accordance with the procedures set forth" in section $706 .{ }^{40}$

\section{Substantive Similarity of Sections 706 and 707}

At first blush it appears that sections 706 and 707 may easily be distinguished: section 706 authorizes suits to redress specific instances of discrimination ${ }^{41}$ while section 707 authorizes suits attack-

ss See id., § 1601.28(a), (b)(1) (1978).

${ }^{36}$ E.g., Williams v. Southern Union Gas Co., 529 F.2d 483 (10th Cir. 1976); EEOC v. Meyer Bros. Drug. Co., 521 F.2d 1364 (8th Cir. 1975). But see Occidental Life Ins. Co. v. EEOC, 432 U.S. 355, 379 n.3 (1977) (Rehnquist, J., joined by Burger, C.J., dissenting in part) ("The Act gives the complaining party the right to disrupt the ostensible federal policy of voluntary settlement by filing suit during the 'window' period from 180 to 270 days after 'the filing of the charge" ").

${ }_{37}$ Act of 1964, \& 707(a).

ss Id.

30 Act of 1972, $\$ 707(\mathrm{e}), 42$ U.S.C. $\$ 2000 \mathrm{e}-5(\mathrm{e})$ (1976).

${ }^{10}$ Id. In United States v. Allegheny-Ludlum Indus., 517 F.2d 826 (5th Cir. 1975), cert. denied, 425 U.S. 944 (1976), the Fifth Circuit, the only circuit to address the issue to date, concluded that only the administrative procedures of section 706 apply in actions under section 707.

In Allegheny-Ludlum, the would-be intervenors argued that the statutory right to intervene, Act of 1972 , $\$ 706(f)(1), 42$ U.S.C. $\$ 2000$ e-5(f)(1) (1976), applied in 707 actions. The court rejected this argument for three reasons, two of which are relevant to the general question of which section 706 procedures apply to 707 actions. First, the court relied, id. at 844 , on a statement in the House Report on the original cease-and-desist bill to the effect that section 707(e) assimilates "procedures for new proceedings brought under section 707 to those now provided under section 706 so that the Commission may provide an administrative 
ing broad "patterns or practices of discrimination." In practice, however, this distinction is difficult to maintain. A section 706 charge necessarily alleges that the employer has discriminated on the basis of a class characteristic. If a class action is possible because the employer has treated many employees in a similar fashion, then it would seem to follow that the employer has engaged in a "pattern or practice" of discrimination. Many section 706 suits can, therefore, be transformed into section 707 suits merely by filing a charge alleging a pattern of discrimination.

There are, however, some differences in the types of suits that may be brought under each section. For example, in order to file a section 706 charge a commissioner must be aware of a specific unlawful employment practice: the employer must be notified of the "date, place, and circumstances of the unlawful employment practice." ${ }^{\prime 2}$ A commissioner may file a section 707 charge without being aware of any individual instances of discrimination. ${ }^{43}$ Section 707

procedure to be the counterpart of the present section 707 action." H.R. REP. No. 238, 92d Cong., 1st Sess. 29 (1971), reprinted in 1972 LegisLative History, supra note 23, at 61, 89. The court interpreted this to mean that only section 706's administrative procedures applied to EEOC suits under section 707. In the cease-and-desist version of section 706 , however, the only section 706 procedures applicable to the EEOC were administrative procedures. H.R. 1746, 92d Cong., 1st. Sess. (as reported from committee June 21, 1971), reprinted in 1972 Legislative History, supra note 23, at 32; S.2515, 92d Cong., 1st Sess. (as reported from committee Oct. 28, 1971), reprinted in 1972 LegrsLatTVE HistoRY, supra note 23, at 344.

Second, the court relied on dicta in a Seventh Circuit case, EEOC v. United Air Lines, Inc., 515 F.2d 946 (7th Cir. 1975), that the statutory right to intervene is not applicable to Attorney General suits. This case is completely inapposite-Attorney General section 707 suits were never under the procedures of section 706. Section 707(e), incorporating the procedures of section 706, applies only to EEOC actions.

Third, the Fifth Circuit relied on the judicially created policy against private intervention in government suits. Such a policy, however, is not relevant to the question of statutory authorization-indeed, it may well have been the existence of such a policy that prompted Senator Williams to provide explicitly for intervention. See 118 Cong. Rac. 4814 (1972), reprinted in 1972 Legislative HistoRy, supra note 23 , at 1670 ("It is likely that such individual would have the right of intervention under Federal rules in civil procedures which the amendment is designed to make clear.").

Furthermore, the policy developed in the context of antitrust suits and its transference to employment discrimination is inappropriate. In antitrust, the government protects competition, not competitors. In Title VII suits, on the other hand, the EEOC is to achieve the public interest in eliminating employment discrimination by enforcing private rights. For a fuller discussion of the inadequacies of the Allegheny-Ludlum rationale, see Sullivan, The Enforcement of Title VII: Meshing Public and Private Efforts, 71 Nw. U.L. REv. 480, 517-20 (1976). It is likely that the Fifth Circuit really reached its conclusion by balancing the interests of the intervenors against what it perceived to be the interest of other aggrieved individuals in obtaining speedy relief. See 517 F.2d at 846.

"A charge must allege that unlawful employment practice has injured a person claiming to be aggrieved. Act of 1972, § 706(b), 42 U.S.C. $\S 2000 \mathrm{e}-5(\mathrm{~b})(1976)$.

12 Id.

is Id., § 707, 42 U.S.C. $\S 2000 \mathrm{e}-6$ (e) (authorizing the EEOC to file a charge that the respondent has engaged in a pattern or practice of discrimination). 
thus enables a commissioner to charge that an employer has engaged in a pattern or practice of discrimination solely on the basis of statistical evidence indicating disparities between the defendant's employment of minorities and the percentage of minorities in the local population. Conversely, a commissioner can file a section 706 charge-but not a section 707 charge-if he knows of only one instance of unlawful discrimination since section 707 charges must allege that the employer has engaged in a "pattern or practice" of discrimination.

Although it is possible to rationalize the continued existence of the two separate enforcement provisions of Title VII, the real difference between sections 706 and 707 is of a much more pedestrian sort. As a general rule, the EEOC brings section 707 suits on the basis of a commissioner's charge; section 706 suits are brought on the basis of individual charges. ${ }^{4}$. Even though this distinction is not in the statute-individuals and commissioners may file charges under either section-courts often think of this as the principal difference between the two sections..$^{45}$ Congress viewed EEOC suits seeking classwide relief under section 706 or section 707 as identical. ${ }^{46}$ The statutory prescription that section 707 actions follow section 706 procedures demands that rule 23 be applied, if at all, uniformly to both sections. ${ }^{47}$

\section{Ambiguity of Congressional Intent Concerning Class Certification}

Congress expected the EEOC to bring class actions ${ }^{48}$ under both

"See Petitioner's Brief for Certiorari at 19, EEOC v. D.H. Holmes Co., 556 F.2d 787 (5th Cir. 1977), cert. denied, 436 U.S. 962 (1978) (pattern-or-practice suits are based on commissioners' charges); 5 Civil Rights Commission, The Federal Civil Rights ENForcement EFForT- 1974, at 554 (1975) [hereinafter volume 5 will be cited as Crvil Rights Commission REPORT] (only commissioner charges are processed as section 707 charges). See generally Comptroller General, The Equal Employment Opportunity Commission Has Made limited Progress in Eliminating Employment Discrimination (1976) [hereinafter cited as COMPTROLLER GENERAL's REPORT] (section 706 charges of individual instances of discrimination are not, apparently, filed by the EEOC).

${ }^{15}$ Cf. EEOC v. Stroh Brewery Co., 19 Fair Empl. Prac. Cas. 1099 (E.D. Mich. 1979) (EEOC sues in the public interest in suits under section 707 but not in suits under section 706).

13 118 Cong. Rec. 4081 (1972), reprinted in 1972 LegrsLative History, supra note 23, at 1589 ("By our decision yesterday [giving the EEOC court-enforcement authority under section 706] we gave the EEOC the power to bring suit in big as well as small cases. . . . [T] EEOC . . . has the authority to institute exactly the same actions that the Department of Justice does under pattern and practice.") (remarks of Sen. Javits). See also note 52 infra.

${ }^{17}$ See text and note at note 40 supra.

4s See, e.g., EEOC v. D.H. Holmes Co., 556 F.2d 787, 792-93 (5th Cir. 1977), cert. denied, 436 U.S. 962 (1978) (EEOC suit under section 707 for broad, classwide relief is class action). 
of the Act's enforcement provisions. Section 707 authorizes the EEOC to bring class suits for injunctive relief, ${ }^{49}$ and the courts have extended the section to allow claims for back pay. ${ }^{50}$ Although section 706 explicitly authorizes the Commission to seek relief only for charging parties, ${ }^{51}$ the legislative history indicates rather clearly that Congress intended to authorize section 706 class actions by the EEOC.52 Whether the provision for class suits was intended to ex-

Contra, EEOC v. Raymond Metal Prods. Co., 17 Fair Empl. Prac. Cas. 206 (D. Md. 1978) (holding that EEOC suits are not class actions and therefore rule 23 is inapplicable); EEOC v. Lutheran Hosp., 10 Fair Empl. Prac. Cas. 1177 (E.D. Mo. 1974) (same); EEOC v. Mobil Oil Corp., 6 Fair Empl. Prac. Cas. 727 (W.D.Mo. 1973) (same); Reiter, supra note 14, at 754 (same). In Mobil, for example, the court recognized that the EEOC action sought relief "for an unknown number of Mobil's past and present employees," but concluded that the EEOC suit "was not a class action." 6 Fair Empl. Prac. Cas. at 727. The Court characterized the EEOC suit as "merely an action by a governmental agency to protect the rights of a potentially large group of citizens." The court missed the point, however. Whether these suits should be labelled class actions is purely a matter of semantics. The real issue, as most courts have recognized, is whether such suits should be brought under rule 23. See, e.g., EEOC v. Stroh Brewery Co., 19 Fair Empl. Prac. Cas. 1099 (E.D. Mich. 1979); EEOC v. Whirlpool Corp., 80 F.R.D. 10 (N.D. Ind. 1978); EEOC v. Page Eng'r, 17 Fair. Empl. Prac. Cas. 1638 (N.D. Ill. 1978).

"Sections 707(a) and 707(e) authorize the EEOC to seek "such relief, including an application for a permanent or temporary injunction, restraining order or other order against the person or persons responsible for such pattern or practice, as . . . [is] necessary to insure the full enjoyment of the rights herein described." Act of 1972, $\S 707(a), 42$ U.S.C. $\$ 2000 \mathrm{e}$ 6(a) (1976).

so See, e.g., United States v. Georgia Power Co., 474 F.2d 906 (5th Cir. 1973).

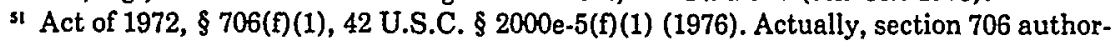
izes the EEOC to seek relief for the charging party or, if the charge is filed on behalf of an aggrieved individual or by the EEOC, section 706 authorizes the EEOC to seek relief for the person "whom the charge alleges was aggrieved by the unlawful employment practice." Id. For the sake of simplicity, however, this comment will use the term "charging party" in the context of section 706 to indicate the person allegedly aggrieved by the unlawful employment practice if the charge was filed on behalf of another or by the EEOC.

32 See 118 Cong. Rec. 4081 (1972), reprinted in 1972 Legislative HistoRy, supra note 23, at 1589 (EEOC suits under the section 706 are "essentially class actions, and if they can sue for an individual claimant, then they can sue for a group of claimants.") (remarks of Sen. Javits). Senator Javits also noted that rule 23 gives "the opportunity to engage in the Federal court in class actions by properly suing parties." Id. at 4082, reprinted in 1972 LegisLative HIsroRY, supra note 23 , at 1590 , and that "[w]e ourselves [Congress] have given permission to the EEOC to be a properly suing party." Id. Senator Williams agreed that "[t]here will be no difference between the cases that the Attorney General can bring under section 707 as a 'pattern and practice' charge, and those which the Commission will be able to bring as a result of yesterday's decision to give EEOC court enforcement powers." Id. at 4081, reprinted in 1972 Legislative History, supra note 23 , at 1587. Cf. Sen. Rep. No. 415, 92ND Cong., Ist Sess. 27 (1971), reprinted in 1972 Legislative History, supra note 23, at 410,436 ("The committee agrees with the courts that title VII actions are by their very nature class complaints"); 4 H. NewBURG, Class Actions \$ 7950, at 1214 (1977) (employment discrimination suits "are, by their very nature, inherent class actions") (footnote omitted). Individuals have always been permitted to bring class actions under section 706. See, e.g., Oatis v. Crown Zellerbach Co., 398 F.2d 496, 499 (5th Cir. 1968). 
empt the EEOC from the normal rule 23 class-action procedures is less clear.

The only reference in the legislative history that bears directly on the issue is a statement made by Senator Javits after the decision to give court-enforcement authority to the EEOC but before the decision to transfer pattern-or-practice authority from the Attorney General to the EEOC. In arguing for the pattern-or-practice transfer, Senator Javits stated that the Comission could "institute exactly the same actions that the Department of Justice does." 53 "These [suits] are," Senator Javits said, "essentially class actions." 54 The Senator was then led to conclude that since rule 23 "give[s] the opportunity to engage in the Federal court in class actions by properly suing parties," 55 and since Congress has "given permission to the EEOC to be a properly suing party," "can proceed by class suit." 57

One recent commentator has concluded that Senator Javits's remarks "clearly demonstrated that he understood that the rule would apply to actions brought by the EEOC,"58 and that "under the court-enforcement approach the Commission would be afforded the opportunity to bring class actions pursuant to the provisions of rule 23." Senator Javits's remarks are not unambiguous, however. He never explicitly stated that the EEOC must, when it brings a class suit, certify under rule 23: he said only that Congress has made the EEOC "a properly suing party."60 Indeed, it might be argued that Senator Javits actually meant that Congress had made the EEOC a properly suing party in class suits without regard to rule $23 .{ }^{81}$ 1589.

s3 118 Cong. REc. 4081 (1972), reprinted in 1972 LegisLATIVE HistoRy, supra note 23, at

st Id.

ss Id. at 4082, reprinted in 1972 Legislative History, supra note 23, at 1590.

st Id.

57 Id., reprinted in 1972 LEgislative HiSTORY, supra note 23, at 1589.

38 Bumpass, supra note 14, at 355 .

so Id. at 354-55.

so 118 Cong. Rec. 4082 (1972), reprinted in 1972 Legislative History, supra note 23, at 1590. See EEOC v. General Tel. Co., 20 Fair Empl. Prac. Cas. 52, 56 (9th Cir. 1979):

While Senator Javits' remarks might be interpreted to signifiy the necessity of complying with Rule 23 , they may also be interpreted to show the breadth of suit which the EEOC would be entitled to bring, rather than indicating that the EEOC would be subject to the procedural requirements of the Rule in bringing a class action.

is See EEOC v. General Tel. Co., 16 Fair Empl. Prac. Cas. 476, 478 (W.D. Wash. 1977), aff'd, 20 Fair Empl. Prac. Cas. 52 (9th Cir. 1979). With the exception of the Ninth Circuit in General Telephone, all courts considering this language have concluded that Senator Javits was addressing the scope of section 707 enforcement authority rather than section 706 . See, 
Two arguments predicated on the legislative intent suggest that EEOC class actions are outside rule $23 .{ }^{62}$ First, Congress may have intended that the EEOC be outside the strictures of the Federal Rules of Civil Procedure and, thus, that EEOC class suits be outside the scope of rule 23 . This argument runs directly counter to the federal rules themselves, however. Rule 1 states that the Federal Rules "govern . . . in all suits . . . with the exceptions stated in Rule 81." Rule 81 makes no mention of any exception for the EEOC. ${ }^{33}$ Moreover, Congress chose to give the Commission court-

e.g., EEOC v. D.H. Holmes Co., 556 F.2d 787, 794 n.11 (5th Cir. 1977), cert. denied, 436 U.S. 962 (1978); EEOC v. Delaware Trust Co., 18 Fair Empl. Prac. Cas. 1521, 1525 (D. Del. 1979); EEOC v. Whirlpool Corp., 80 F.R.D. 10, 17 (N.D. Ind. 1978). Although it is true that the statement was made during the debate on amending section 707 , careful reading of the debate indicates that the Senator was directly addressing enforcement under section 706 , not section 707. He was arguing that section 707 should be amended to transfer pattern-or-practice enforcement authority to the EEOC because the EEOC could bring class actions under section 706.

12 Some district courts have offered other arguments with little analysis. Several courts, for example, have stated that since the EEOC's authorization to sue is statutory, it need not comply with rule 23. EEOC v. Singer Controls Co., 80 F.R.D. 76, 79 (N.D. Ohio 1978); EEOC v. General Tel. Co., 16 Fair Empl. Prac. Cas. 476, 479 (W.D. Wash. 1977), aff'd, 20 Fair Empl. Prac. Cas. 52 (9th Cir. 1979); EEOC v. Rexene Polymers Co., 10 Fair Empl. Prac. Cas. 61, 62 (W.D. Tex. 1975). This approach ignores three key issues. First, Congress may have intended rule 23 to be applicable to EEOC suits; if so, the EEOC statutory authorization is not an exemption from the rule. Second, rule 23 is a joinder device that is appropriate in cases in which the plaintiff has authority to sue but nonparties, too numerous to join, will be prejudiced if not joined. See text and notes at notes 155-164 infra. Finally, courts have not hesitated to apply other rules of civil procedure to government enforcement actions under Title VII. See Bumpass, supra note 14, at 359-60 (citing International Bhd. of Teamsters v. United States, 431 U.S. 324, 356 n.43 (1977) (rule 19 applied); United States v. AlleghenyLudlum Indus., 517 F.2d 826, 840, 876-77 (5th Cir. 1975), cert. denied, 425 U.S. 944 (1976) (rules 19 and 24 applied)).

${ }^{6}$ FED. R. Crv. P. 81. See EEOC v. D.H. Holmes Co., 556 F.2d 787, 795 (5th Cir. 1977), cert. denied, 436 U.S. 962 (1978). As a general proposition, government agencies must follow the usual judicial procedures when bringing suit. See United States v. Procter \& Gamble, 356 U.S. 677, 681 (1958) (government under discovery procedures like any other litigant); 4 C. Wright \& A. Miller, Federal Practice and Procedure $\$ 1027$, at 118 n.60 (1969) ("The original Advisory Committee was pressed by government attorneys to make special provisions in the rules for cases in which the United States is a litigant. A few special provisions were found to be necessary, but on the whole the federal rules provide for precisely the same practice in government cases as in private litigation. Exceptions were made only when justified by experience and actual conditions."); Holtzolf, Procedural Rules when Government Is a Litigant, 26 A.B.A.J. 391, 391 (1940) ("We start with the premise that the rules, except when otherwise specified, apply with equal force to the government as a litigant as they do to private parties.").

Several district courts have held rule 23 inapplicable to EEOC suits because the EEOC has standing to sue in its own name to vindicate the public interest. EEOC v. Raymond Metal Prods. Co., 17 Fair Empl. Prac. Cas. 206 (D.C. Md. 1978); EEOC v. Schlueter Mfg. Co., 17 Fair Empl. Prac. Cas. 53 (E.D. Mo. 1978); EEOC v. Pinkerton's, Inc., 14 Fair Empl. Prac. Cas. 1431 (W.D. Pa. 1977); EEOC v. CTS of Ashville, Inc., 13 Fair Empl. Prac. Cas. 852, 853 (W.D.N.C. 1976); EEOC v. Lutheran Hosp., 10 Fair Empl. Prac. Cas. 1177, 1178 (E.D. 
enforcement rather than cease-and-desist authority in part because it wished to ensure that employers would be given the benefit of the Federal Rules of Civil Procedure and Evidence. ${ }^{64}$ Without any other indication in the legislative history-and there is none-it is untenable to conclude that Congress intended the EEOC to be outside the strictures of the Federal Rules,and, thus, that EEOC class suits be outside rule $23 .{ }^{65}$

A second argument was advanced by the district court in $E E O C$ v. General Telephone Co. ${ }^{66}$ That court began by noting that "the Attorney General was never required to comply with Rule 23 in order to bring a pattern or practice suit." ${ }^{67}$ The court went on to say that " $[t]$ here is nothing in the statute to suggest that Congress intended Rule 23 to apply to the EEOC where it had not previously

Mo. 1974). See also EEOC v. Vinnell-Dravo-Lockheed-Mannix, 417 F Supp. 575 (E.D. Wash. 1976). This rationale rests on the assumptions that the EEOC sues in the public interest, and that it does not sue as the representative of the victims of discrimination. Legislative history, however, indicates otherwise. See text and notes at notes 90-107 infra.

s4 See, e.g., 118 Cong. Rec. 932 (1972), reprinted in 1972 Legislative History, supra note 23,807 (court enforcement should be chosen so that defendants have the protections "of the customary and time-honored rules of evidence and procedure") (remarks of Sen. Allen); id. at 3810 , reprinted in 1972 LEgIALTIVE HISTORY, supra note 23, at 1485 ("you can do far better in a court proceeding which is impartial, organized, and ruled by precedent and established rules of procedure than you can from an administrative proceeding") (remarks of Sen. Dominick); 117 CONG. REc. 32098 (1971), reprinted in 1972 Legialtive History, supra note 23, at 278 ("I might suggest to the committee that abandonment of formal rules of evidence does not guarantee the equitable disposition of cases. It does not adhere to the noble and timetested traditions of America, the tradition of the rule of law, the tradition of granting each party his day in court and the fullest protection of all rules, procedural and evidentiary, on the statute books.") (emphasis added) (remarks of Rep. Mazzoli); 118 CoNG. REc. 593 (1972), reprinted in 1972 LEGISLATIVE HistoRY, supra note 23, at 678 (with court proceedings, matters will be handled "on the same objective, fair basis that the Federal district courts have been handling cases before them of all kinds for a long period of time") (remarks of Sen. Dominick).

Congress was aware of the fact that application of the Federal Rules of Evidence and the Federal Rules of Civil Procedure could impede enforcement. As the House report accompanying the cease-and-desist bill pointed out, "administrative tribunals are less subject to technical rules governing such matters as pleadings and motion[s]." H.R. REP. No. 238, 92nd Cong., 1st Sess. 11 (1971), reprinted in [1972] U.S. CoDE Cong. \& AD. NEws 2137, 2146, and 1972 Legislative History, supra note 23, at 61, 71. See also 117 Cong. Rec. 31960 (1971), reprinted in 1972 Legislative History, supra note 23, at 196 (remarks of Rep. Perkins).

as In Title III of the Hart-Scott-Rodino Antitrust Improvement Act of 1976, 15 U.S.C. $\S \S 15 \mathrm{c}-15 \mathrm{~h}$ (1976), Congress authorized class actions outside rule 23 , but provided procedural protections parallel to those of rule 23 , for example, notice, opt-out, and res judicata protection for defendants.

${ }^{66} 16$ Fair Empl. Prac. Cas. 476 (W.D. Wash. 1977), aff'd, 20 Fair Empl. Prac. Cas, 52 (9th Cir. 1979). Accord, EEOC v. Singer Controls Co., 80 F.R.D. 76 (N.D. Ohio 1978); EEOC v. Whirlpool Corp., 80 F.R.D. 10 (N.D. Ind. 1978); EEOC v. Akron Nat'l Bank \& Trust Co., 78 F.R.D. 684 (N.D. Ohio 1978).

67 16 Fair Empl. Prac. Cas. at 478. 
applied to the Attorney General." ${ }^{\text {88 }}$ The court thus concluded that "[a]bsent express language in the statute, this court should not impose restrictions on the EEOC that were not imposed on the Attorney General." ${ }^{69}$ In essence the argument is that Congress, by taking no action and by expressing no contrary view, approved the Attorney General's practice of not complying with rule 23 and that, since EEOC pattern-or-practice suits are virtually equivalent to Attorney General suits, EEOC suits are not subject to rule 23.

This line of reasoning is subject to a number of difficulties, however. First, contrary to the assertion of the General Telephone district court, it is not true that "[t]he 1972 amendments merely transferred the authority to bring pattern and practice suits from the Attorney General to the EEOC."ז0 Section 707(e), added by the 1972 amendments, requires that "[a]ll . . . actions [under section 707] shall be conducted in accordance with the procedures set forth in section" $706 .{ }^{71}$ This addition suggests that it is improper to judge congressional intent by reference to section 707 alone. On procedural matters, section 706-not section 707-controls.

Second, although compliance with rule 23 was not required in any of the Attorney General suits, the Attorney General brought relatively few suits, ${ }^{72}$ and in none of them was the rule 23 issue raised. ${ }^{73}$ It would be one thing to impute the noncompliance-withrule-23 intent to Congress had the issue been raised in litigation; it is another to follow that approach when the issue was raised neither in court nor in the extensive congressional debates on the 1972 amendments. As the Ninth Circuit apparently recognized on appeal, the approach of the district court in General Telephone must be rejected as unconvincing $;^{74}$ the legislative history simply fails to support the district court's conclusion.

Third, subsequent expansion of the section 707 cause of action suggests that the applicability of rule 23 to section 707 should be determined by the practice under section 706 . Section 707 practice was established at a time when the section was construed as author-

"Id.

"Id.

io Id.

$"$ Act of 1972, § 707(e), 42 U.S.C. § 2000e-6(e) (1976).

iz In the seven years before the debate on the 1972 amendments, the Attorney General brought 69 cases. 118 Cong. Rec. 4080 (1972), reprinted in 1972 LeGisLative HistoRY, supra note 23 , at 1587 .

is See, e.g., United States v. Iron Workers Local 86, 443 F.2d 544 (9th Cir.), cert. denied, 404 U.S. 984 (1971).

"See EEOC v. General Tel. Co., 20 Fair Empl. Prac. Cas. 52, 57, 59-60 (9th Cir. 1979). 
izing only injunctive relief. ${ }^{75}$ Although later constructions of the section have permitted the recovery of back pay, when the 1972 amendments were passed, the Attorney General did not normally seek back pay in suits under section $707,{ }^{76}$ and it was considered doubtful that he could do so. ${ }^{77}$ There is little reason to suppose, therefore, that Congress intended to exempt the EEOC from rule 23 in section 706 suits for classwide back pay on the basis of the Attorney General's practice under section 707.

The rationale used in allowing recovery of back pay in suits under section 707 bolsters this point. In United States v. Georgia Power Co. ${ }^{78}$ the Fifth Circuit became the first circuit to hold that back pay was an available remedy under section $707 .{ }^{79}$ The court began with the legislative history of the 1964 Act, pointing out that H.R. 7152, the original bill, provided for EEOC and private enforcement in a section equivalent, for purpose of this discussion, to section $706 .{ }^{80}$ When this bill was filibustered in the Senate, the bill actually enacted was presented as a compromise. The EEOC was given no enforcement authority, but the Attorney General was authorized to bring pattern-or-practice suits. Since the Commission had been authorized to seek back pay under the terms of the original bill, and since the substitute "was not seen by either proponents or opponents as providing any less comprehensive relief," the Fifth Circuit concluded it was unlikely that Congress had intended to preclude the Attorney General from seeking back pay. ${ }^{81}$ Moreover, the 1972 amendments clearly authorized the EEOC to sue for back pay under section 706 . The court therefore concluded, "We think it incongruous that 'Congress would have thought it appropriate to give the EEOC . . . authority to sue for back pay under Section 706 but not in cases involving the more serious Section 707 problems." $"$ "'

Given this rationale for allowing recovery of back pay in section 707 suits, the previous practice of not certifying section 707 class actions is especially inapposite when monetary relief is sought. The EEOC has authority to seek back pay in suits under section 707

is See, e.g., United States v. Georgia Power Co., 474 F.2d 906 (oth Cir. 1973).

is See Developments in the Law-Title VII, 84 Harv. L. Rev. 1109, 1243 (1971).

"See, e.g., United States v. Local 3, Int'l Union of Operating Eng'rs, 4 Fair Empl. Prac. Cas. 1088, 1093 n.1 (N.D. Cal. 1972).

7x 474 F.2d 906 (5th Cir. 1973).

ig Georgia Power was followed by other circuits, see, e.g., EEOC v. Detroit Edison Co., 515 F.2d 301, 314-15 (6th Cir. 1975), and remains the definitive decision on the issue.

xo 474 F.2d at 920 (discussing H.R. 7152, 88th Cong., 1st Sess. (1963) (as reported from committee Nov. 20,1963), reprinted in. 1964 Legislative History, supra note 23, at 2001).

*1 474 F.2d at 920 .

${ }^{x 2} I d$. 
because it can do so (and was intended to do so originally) under section 706. The certification issue in suits for back pay should, therefore, be determined in terms of section 706. If the Commission must use rule 23 to join those for whom it seeks back pay in suits under section 706, then it must also do so in suits under section 707 .

It could be argued that, although inapplicable to suits for back pay, the section 707 practice is applicable to suits for injunctive relief. Nevertheless, this distinction breaks down upon closer examination. Injunctive relief may run as directly to individuals as monetary relief, and joinder of absent aggrieved individuals is, if anything, even more appropriate in suits for injunctive relief-for example, to protect the defendant from the risk of future inconsistent injunctions. Moreover, even in injunctive actions under section 707, the 1972 amendments require that section 706 procedures be applied. The question of the applicability of rule 23 to EEOC suits cannot, therefore, be resolved in terms of the scope of the EEOC's statutory authorization under section 707 .

On the other hand, it can be argued that since section 706 and its procedures are controlling, the rule 23 question should be resolved in terms of the scope of the EEOC's statutory authorization in that section. Since section 706 explicitly authorizes the EEOC to sue only on behalf of charging parties, under this analysis, the Commission must seek certification as a class representative in order to have standing to assert classwide claims. ${ }^{83}$ This approach, although apparently conforming to congressional intent by treating the scope of the EEOC's statutory authorization as determinative, may be overly technical.

The statute does not, despite the limited scope of the Commission's authorization, clearly indicate that Congress intended the EEOC to bring class actions within the framework of rule 23's procedural safeguards. Since the statute and legislative history are ambiguous, the question should be resolved in favor of the solution most consistent with the general statutory scheme of Title VII. Congress would not, of course, have intended rule 23 to apply if it thought application of the rule would frustrate Title VII enforcement. It is, therefore, necessary to examine the impact of requiring EEOC certification as class representative on Title VII enforcement.

Both the EEOC and the courts that accept its contention that it need not certify its class suits as rule 23 class actions have intro-

*3 Courts requiring the EEOC to seek certification as a class representative in suits under 706 have relied heavily on the limited scope of the EEOC's authorization under that section. See, e.g., EEOC v. D.H. Holmes Co., 556 F.2d 787, 794 (5th Cir. 1977), cert. denied, 436 U.S. 962 (1978). 
duced a public-interest rhetoric to the debate by viewing the EEOC's enforcement role as dualistic: although its suits spring from its power to protect private rights to equal employment opportunities, the goal of these suits is allegedly to protect a public interest that transcends the private rights involved. ${ }^{84}$ That view was stated succinctly by a district court in EEOC $v$. Whirlpool Corp.. ${ }^{45}$

[T]he Commission's first responsibility is to the . . . public. The Commission must represent the public interest as well as the interests of the ... charging parties ....

Recognizing the fundamental distinction between the private and public interest, courts have acknowledged that a federal agency may not necessarily be able to serve both those interests at once. ${ }^{86}$

In EEOC $v$. General Telephone Co., the Ninth Circuit went so far as to state that the EEOC "promotes public policy and seeks to vindicate rights belonging to the United States as sovereign."

The public-interest aspect of the EEOC's enforcement efforts has led some courts to conclude that it either cannot or need not comply with rule 23 when bringing class suits. 88 The Commission's ability to comply with rule 23 prerequisites will be examined in depth later. ${ }^{89} \mathrm{It}$ is important to demonstrate at the outset, however, that the dualistic view of EEOC enforcement is flawed in theory and as a construction of congressional intent.

\section{A Private Rights' View of EeOC Action in the Public INTEREST}

The dualistic view of the EEOC's role as Title VII enforcer rests on a perception that the public interest in equal employment opportunity exceeds the totality of private interests protected by Title VII. Its theoretical perspective markedly contrasts with the more limited view that the public interest in elimination of employment discrimination is to be served by enforcing the rights of the individ-

* See, e.g., EEOC v. General Tel. Co., 20 Fair Empl. Prac. Cas. 52, 56-59 (9th Cir. 1979); EEOC v. Akron Nat'l Bank \& Trust Co., 78 F.R.D. 684, 687-88 (N.D. Ohio 1978); EEOC v. Whirlpool Corp., 80 F.R.D. 10, 13-19 (N.D. Ind. 1978).

*s 80 F.R.D. 10 (N.D. Ind. 1978).

so Id. at 13-14 (citations omitted).

*7 20 Fair Empl. Prac. Cas. 52, 57 (9th Cir. 1979) (quoting EEOC v. Occidental Life Ins. Co., 535 F.2d 533, 537 (9th Cir. 1976), aff'd, 432 U.S. 355 (1977)).

${ }^{*}$ See, e.g., EEOC v. Akron Nat'l Bank \& Trust Co., 78 F.R.D. 684 (N.D. Ohio 1978) (because EEOC cannot satisfy rule 23 prerequisites, it cannot bring class, actions under section 706, but it may bring a "statutory class action" outside the provisions of rule 23 under section 707).

"See Part III infra. 
ual victims of discrimination. ${ }^{90}$ The difference between these positions may be described by reference to the source of the Commission's power. If its power derives from the legitimate claims of individuals to fair employment practices, its role should be limited to enforcing individual rights; if, on the other hand, the EEOC was granted enforcement authority to enforce a broad public claim to a nondiscriminatory society, it may well be that individual claims to fair treatment are of only secondary importance. What is apparently unrecognized by the public-rights analysis is that the conclusion that Title VII creates a "national policy of equal opportunity in employment" does not define the paramenters of that policy or explain the EEOC's role in promoting it. As the Fifth Circuit pointed out in EEOC v. D.H. Holmes Co., uncritical invocation of the public interest in Title VII enforcement "misses the point; presumably the Government vindicates some congressional policy whenever it sues."91

The development of the Title VII enforcement sections demonstrates that Congress conceived the EEOC's court-enforcement function as limited to redressing denials of individual rights to equal employment opportunities. Title VII originally provided that the individual suit play the central role in enforcement. Congress soon became dissatisfied with enforcement by the victims of discrimination: it did not want the burden of enforcement to fall on those whose economic disadvantage was the reason for the enactment of Title VII, ${ }^{22}$ and it preferred voluntary compliance to court enforce-

${ }^{90}$ See, e.g., EEOC v. D.H. Holmes Co., 556 F.2d 787 (5th Cir. 1977), cert. denied, 436 U.S. 962 (1978).

" Id. at 792 n.7. The Supreme Court rejected a similar assertion that the Labor Act created a dichotomy of interests in UAW Local 283 v. Scofield, 382 U.S. 205 (1965). In Scofield, the NLRB opposed the intervention of the charging party in the appellate review of the NLRB's judgment on his behalf. Id. at 217-18. The NLRB argued that it was charged with protecting the public interest and the charging party was merely the beneficiary of the NLRB order. The Board added that it was the "custodian of the "public interest"'-to the exclusion of any private interests. Id. at 218. Rejecting.the NLRB's assertions, the Supreme Court referred to "the rhetoric of 'public interest," " $i d$. at 218, and pointed out "that the statutory pattern of the Labor Act does not dichotomize 'public' as opposed to 'private' interests. Rather, the two inter-blend in the intricate statutory scheme." Id. at 220 . In reaching its conclusions, the Court cited Professor Jaffee's article criticizing public rights rhetoric, $i d$. at $218 \mathrm{n} .12$, in which Jaffee points out: "It is . . . one of the fundamental insights or premises of democratic theory that all lines of value lead back to the individual." Jaffee, The Public Right Dogma in Labor Board Cases, 59 HaRv. L. Rev. 720, 725 (1946). The "public rights rhetoric" in the debate over EEOC class-action certification has a parallel flaw. Title VII does not create a dichotomy between public and private interests but merely creates a public agency to enforce private rights that might otherwise be inadequately protected.

"2 See S. REP. No. 415, 92nd Cong., 1st Sess. 4 (1971), reprinted in 1972 Legislative HistoRY, supra note 23 , at 410,413 (the burden of enforcement should not rest on those whose 
ment. ${ }^{93}$ Congress felt that defendants all too often ignored the EEOC's voluntary compliance process, relying on the charging party's inability to afford a compliance suit..$^{94}$ By giving the.EEOC enforcement power, Congress hoped to correct both problems.

Congress retained the individual's right to sue under section 706 not because the Commission was to represent the public interest rather than the interests of the individual victims of discrimination, but because it had a substantial backlog..$^{95}$ In addition, Congress did not want agrieved individuals to be bound solely by an EEOC determination that there was no reasonable cause to believe a violation of Title VII had occurred..$^{98}$ These views are succinctly stated in the section-by-section analysis of the final version of the Conference Bill:

It is hoped that recourse to the private lawsuit will be the exception and not the rule, and that the vast majority of complaints will be handled through the offices of the EEOC . . . . However, as the individual's rights to redress are paramount under the provisions of Title VII it is necessary that all avenues be left open for quick and effective relief. ${ }^{87}$

One rather subtle aspect of the legislative history indicates that, as far as Congress was concerned, the EEOC has no interest under section 706 other than enforcing the rights of aggrieved individuals. The initial bills in both houses authorized the EEOC to

economic disadvantage led to the enactment of Title VII-and who often are unable to afford a suit).

${ }^{93}$ See, e.g., 118 Cong. Rec. 1069 (1972), reprinted in 1972 Legislative History, supra note 23 , at 892 ("what we are trying to do' . . . is to have the unlawful employment practice charge solved by voluntary compliance. I think that all of us prefer to see this rather than a commission filing a cease-and-desist order, or as in my amendment, having to go to court.") (remarks of Sen. Dominick).

"See, e.g., id. at 931, reprinted in 1972 LegisLative History, supra note 23, at 805 ("The Equal Employment Opportunity Commission is now unarmed other than being able to attempt to conciliate through persuasion and agreement where there is now discrimination. There can be little incentive to agreement because there is no enforcement authority behind conciliatory practice.") (remarks of Sen. Williams).

${ }^{95}$ See, e.g., H.R. REP. No. 238, 92nd Cong., 1st Sess. 12 (1971), reprinted in [1972] U.S. Code Cong. \& AD. NEws 2137, 2147-48, reprinted in 1972 LEgIsLATIVE HistoRY, supra note 23 , at 61, 72 ("the private right of action, both under the present Act and in the bill, provides the aggrieved party a means by which he may be able to escape from the administrative quagmire which occasionally surrounds a case caught in an overloaded administrative process").

${ }^{86}$ See Act of $1972 \S 706(f)(1), 42$ U.S.C. $\S 2000$ e-5(f)(1) (1976) (if a charge is dismissed by the EEOC for lack of "reasonable cause," the EEOC is to issue a right-to-sue letter).

1118 Cong. Rec. 7168 (1972), reprinted in 1972 LegisLative HistoRy, supra note 23, at 1847 (emphasis added). 
hold hearings and issue cease-and-desist orders against respondents. ${ }^{98}$ Since the Commission already had a substantial backlog, individuals were to be allowed to sue in district court if the EEOC had not processed their charges within 180 days. ${ }^{99}$ Under these bills, the EEOC's only power was its ability to issue cease-and-desist orders on behalf of charging parties; once the charging party sued in court, its jurisdiction ended. The Commission's only function was to enforce the rights of those individuals who came before it.

Although the EEOC was finally given power to sue in district court rather than issue cease-and-desist orders, its function, as defined in the cease-and-desist bills, is relevant to the 1972 amendments. The only issue in the choice between cease-and-desist authority and court enforcement was the relative effectiveness and fairness of the two enforcement devices. ${ }^{100}$ Congress did not view its choice of court enforcement as expanding the EEOC's powers beyond the limited ability to act on behalf of charging parties granted in the original bill. In fact, the substantive language of the court enforcement provisions closely parallels the wording of the ceaseand-desist provisions. ${ }^{101}$

The Supreme Court apparently adopted the view that the EEOC sues on behalf of the victims of discrimination in section 706 suits in Occidental Life Insurance Co. v. EEOC. ${ }^{102}$ In Occidental the Court held that the EEOC was exempt from state statutes of limitations in suits seeking back pay. The Court considered such statutes inconsistent with the EEOC's congressionally mandated responsibilities as "a federal administrative agency charged with the responsibility of investigating claims of employment discrimination and settling disputes, if possible, in an informal, noncoercive fashion."103

is H.R. 1746, 92d Cong., 1st Sess. (as reported from Committee June 2, 1971), reprinted in 1972 Legislative History, supra note 23, at 32; S. 2515, 92d Cong., 1st Sess. (as reported from Committee Oct. 28, 1971), reprinted in 1972 LEgISLATIVE History, supra note 23, at 344.

" H.R. 1746 at 55-56, reprinted in 1972 Legislative History, supra note 23, at 32, 54-55; S. 2515 at 49 , reprinted in 1972 LEGISLATIVE HistoRY, supra note 23, at 392-93.

100 See, e.g., 118 Cong. REc. 1511 (1972), reprinted in 1972 LEgISLATIVE History, supra note 23 , at 974 ("the purpose . . . [of both bills] is to provide enforcement machinery for the orders of the EEOC") (remarks of Sen. Allen); id. at 696, reprinted in 1972 LEGISLATIVE History, supra note 23, at 690 ("The issue . . . is . . . what form and scope of enforcement is needed to best protect the rights of all parties involved.") (remarks of Sen. Dominick); id. at 595, reprinted in 1972 LegisLative HistoRY, supra note 23, at 684 (the issue is "whether court enforcement as an exclusive method is the most efficient way of reaching the objectives of the legislation") (remarks of Sen. Williams).

103 Compare S. 2515, 92d Cong., 1st Sess. $39-40$ (as reported from committee Oct. 28, 1971), reprinted in 1972 Legrslative History, supra note 23 , at $344,382-83$ with The Equal Employment Opportunity Act of 1972, Pub. L. No. 92-261, 86 Stat. 103, at 107.

102432 U.S. 355 (1977).

105 Id. at 368 . 
The Court implied, however, that the EEOC litigates on behalf of private parties. After stating that "the EEOC does not function simply as a vehicle for conducting litigation on behalf of private parties," 104 the Court based its decision solely on the conflict between the EEOC's administrative responsibilities and the time constraints of state statutes of limitations-not on any notion that the EEOC litigates on behalf of public, rather than private interests.

In dissent, joined by the Chief Justice, Justice Rehnquist emphasized the limited role of the EEOC in Title VII enforcement. The EEOC sues "as a conduit for the recovery of sums due an individual citizen rather than the public treasury." When the Commission seeks injunctive relief, even though "broad based," it nonetheless seeks redress for individuals, not enforcement of the rights of the United States as sovereign. ${ }^{105}$

Congress did give charging parties a statutory right to intervene in an EEOC suit on their behalf. ${ }^{108}$ This has been treated as an implicit congressional recognition that the EEOC enforcement of the public interest may conflict with the interests of aggrieved individuals. ${ }^{107}$ It seems more likely, however, that Congress was not endorsing a broad "public interest" view of the EEOC when it provided for intervention, but was merely recognizing that the EEOC's actions would not necessarily provide perfect protection for individual rights. Had Congress viewed EEOC enforcement as designed to promote a public interest that conflicted with private rights, - it would more likely have denied individuals the right to intervene, thus ensuring that the EEOC could use its power to sue to promote its vision of the public interest without interference by individuals. Although it is certain that the EEOC's view of its role may occasionally jeopardize private interests, thus making intervention an important right, there is no evidence that Congress intended

104 Id. In EEOC v. General Tel. Co., 20 Fair Empl. Prac Cas. 52 (9th Cir. 1979), the Ninth Circuit relied heavily on its own decision in EEOC v. Occidental Life Ins. Co., 535 F.2d 533 (9th Cir. 1976), to support the proposition that the EEOC sues in the public interest. In Occidental Life, the Ninth Circuit had held that the EEOC was exempt from state statutes of limitations because it "promotes public policy and seeks to vindicate rights belonging to the United States as sovereign." Id. at 537. Although admitting that the Supreme Court had not expressly adopted that view, the General Telephone court concluded that the Supreme Court "clearly recognizes a distinction between actions instituted by the EEOC and private class actions by complainants." 20 Fair Empl. Prac. Cas. at 57 n.17. Yet, the only distinction recognized by the Supreme Court was that the EEOC, unlike private litigants, has congressionally imposed administrative responsibilities.

105432 U.S. at 383.

${ }^{108}$ Act of 1972, § 706(f)(1), 42 U.S.C. \& 2000e-5(f)(1) (1976).

${ }^{107}$ See EEOC v. Whirlpool Corp., 80 F.R.D. 10, 15 (N.D. Ind. 1978). 
subordination of those interests to the Commission's notions of the public good.

Although the 1972 amendment to Title VII effected major changes in the EEOC's enforcement role, Congress did not alter the underlying philosophy of the Act. Both before and after the amendments, Title VII was intended to promote equality in employment opportunities by creating individual rights to such equality. These rights were made enforceable by the courts at the behest of individuals and the EEOC. The theme in both EEOC and private enforcement was to be the same: redress of individual rights. Such redress, whether achieved through conciliation, EEOC suit, or private suit, is the means by which Congress expected the "national policy of equal opportunity in employment" to be achieved. The public interest in Title VII enforcement does not transcend the interests of individual victims of discrimination; it parallels them and receives its fullest vindication when private rights are vindicated.

Once it is recognized that the EEOC's primary responsibility is to represent and enforce private rights, the fundamental objection to rule 23 certification - that the very nature of the EEOC's role makes it an inadequate representative of the individuals whose rights are involved in the suit-becomes unpersuasive. The remainder of this comment will analyze the Commission's compliance with rule 23 in light of its obligation to protect individual rights. The focus will be on the availability of certification and the procedural and institutional advantages certification would bring to Title VII enforcement.

\section{The EEOC's Ability to Satisfy Rule 23's Prerequisites}

\section{A. Class Membership Requirement}

Rule 23(a) begins with the words "[o]ne or more members of a class may sue or be sued." 108 This language potentially defeats the EEOC's ability to certify as a rule 23 class representative since it is obviously not a class member. In EEOC $v$. Whirlpool Corp., ${ }^{109}$ the district court termed the membership language "the most fundamental requirement of Rule 23(a),"110 and concluded that "the Com-

10s Rule 23(a) ("Prerequisites to a Class Action") provides that:

One or more members of a class may sue or be sued as representative parties on behalf of all only if (1) the class is so numerous that joinder of all members is impracticable, (2) there are questions of law or fact common to the class, (3) the claims or defenses of the representative parties are typical of the claims or defenses of the class, and (4) the representative parties will fairly and adequately protect the interests of the class. 10980 F.R.D. 10 (N.D. Ind. 1978).

110 Id. at 14 . 
mission can never fulfill the requirements of Rule 23 because it is not a member of the class."111 That court, and other courts that refuse to certify the EEOC as a class representative, ${ }^{112}$ rely heavily upon the public-interest role of the EEOC discussed and rejected above. Even though Congress provided the Commission with standing to sue on the claims of private parties, these courts contend that because standing was conferred only to allow the EEOC to sue in the public interest, it does not vest the EEOC with status as an individual class member, and therefore the EEOC cannot satisfy the membership language of rule 23 .

This line of reasoning was considered and rejected by the Fifth Circuit in EEOC v. D.H. Holmes Co. The EEOC argued that "as a matter of law" it could "never satisfy the requirements of Rule 23 because it [was] . . . not itself a member of the class." 113 The court rejected the EEOC's argument:

[I]t would seem to be Congress' clear intent that EEOC stand in the shoes of . . . individuals and represent them in a suit the individuals would otherwise be entitled to bring. Where individuals can institute Title VII suits under Rule 23 , it would be anomalous in the extreme to hold that EEOC, an enforcement agency expressly authorized by Congress to sue, may never do so under Rule 23 solely because it runs afoul of the membership requirement.

.. . Having been set up by the law to bring civil actions on behalf of persons allegedly discriminated against, EEOC has standing to sue, is a real party in interest, and . . . for purposes of Rule 23, is a member of the class. ${ }^{114}$

"11 Id. Accord, EEOC v. General Tel. Co., 16 Fair Empl. Prac. Cas. 476, 479 (W.D. Wash. 1977), aff'd, 20 Fair Empl. Prac. Cas. 52 (9th Cir. 1979) ("Clearly, the EEOC can never be a member of a class of employees who have been discriminated against."). See EEOC v. General Tel. Co., 20 Fair Empl. Prac. Cas. 52, 55 (9th Cir. 1979) ("Based solely upon the language of Rule 23, it can be argued that the Rule does not apply to actions brought by the EEOC to enforce Title VII rights. The EEOC obviously is not a member of the 'class' it represents.").

112 See, e.g., EEOC v. General Tel. Co., 20 Fair Empl. Prac. Cas. 52 (9th Cir. 1979); EEOC v. Akron Nat'l Bank \& Trust Co., 78 F.R.D. 684 (N.D. Ohio 1978).

${ }^{113} 556$ F.2d 787, 796 (5th Cir. 1977), cert. denied, 436 U.S. 962 (1978).

il Id. at 796-97 (footnotes omitted). Discussion of the technical membership requirement was left to a footnote:

The membership language of Rule 23 seems directed at individuals. It has, however, been applied to organizations and certain orgainizations have been permitted to bring class actions even though not themselves members of a class . . . .

Where organizations, formed by their membership for purposes of mutual benefit, yet not themselves members of a class, have sued under Rule 23 , it would be incongruous 
The restrictive view of the membership requirement adopted by the Whirlpool court, rests upon a close reading of the Supreme Court's holding in East Texas Motor Freight v. Rodriguez:"11 "a class representative must be part of the class and 'possess the same interest and suffer the same injury' as the class members." literally, that language supports the proposition that mere standing to sue will not satisfy the membership requirement. The purported class representative must, apparently, be an individual member of the class. The Supreme Court, however, cast doubt on the plausibility of such a literal reading by its reliance, in Rodriguez, upon cases that treat class membership as equivalent to a requirement that the prospective class representative have standing to sue. ${ }^{17}$ The Rodriguez court did not explicitly reject that equivalence, and it seems a sensible interpretation of rule 23's membership language. One concern with class actions, as with all representative actions, is that an actual case or controversy exist between the named plaintiff and the defendant. ${ }^{118}$ The membership requirement, viewed as a standing requirement, fulfills the constitutional requirement of a case or controversy. Any more restrictive reading can only serve to ensure that the named plaintiff will adequately represent absent parties. The prerequisites to a class action enumerated in rule 23(a), however, provide a functional approach to the adequacy problem, that makes a formalistic and inflexible reading of the membership language unnecessary.

Courts frequently allow parties who are technically not class members to serve as rule 23 representatives. Rule 23 class actions have, for example, been brought by associations, ${ }^{119}$ unions, ${ }^{120}$ the

to hold that EEOC cannot.

Id. at 796 n.15.

115431 U.S. 395 (1977).

116 Id. at 403.

17 See, e.g., Schlesinger v. Reservists Comm. to Stop the War, 418 U.S. 208, 216 (1974) (to act as a class representative, plaintiff must "possess the same interest and suffer the same injury" as members of the class); Rosario v. Rockefeller, 410 U.S. 752, 759 n.9 (1973) (equating lack of standing with absence of class membership); Bailey v. Patterson, 369 U.S. 31, 3233 (1962) (appellants lack standing and are therefore not members of the class for which they seek relief).

ik See, e.g., Sosna v. Iowa, 419 U.S. 393, 398-99 (1975).

i' E.g., Arkansas Educ. Ass'n v. Board of Educ., 446 F.2d 763 (8th Cir. 1971); Thompson v. Board of Educ., 71 F.R.D. 398 (W.D. Mich. 1976). See National Automatic Laundry \& Cleaning Council v. Shultz, 443 F.2d 689, 704 (D.C. Cir. 1971). Cf. Simon v. Eastern Ky. Welfare Rights Org., 426 U.S. 26, 40 (1976) (organization must establish injury to itself or to any of its members in order to have standing to sue); United States Civil Serv. Comm'n v. National Ass'n of Letter Carriers, 413 U.S. 548, 551 n.2 (1973) (national association adequately represents federal employees, but not state employees under rule $23(\mathrm{a})$ ). These cases are under rule 23 , not rule 23.2. The latter rule covers only unincorporated associations suing 
next friend of a minor, ${ }^{121}$ trustees, ${ }^{122}$ executors, ${ }^{123}$ and bankruptcy trustees. ${ }^{124}$ State attorneys general, with the requisite standing under local law, have been allowed to represent rule 23 classes in federal courts in cases in which the state is not technically a member of the class-for example, in cases in which the class is the school districts in the state. ${ }^{125}$ In many of these cases the class membership requirement is never even discussed. ${ }^{126}$ Courts, in allowing this type of rule 23 representative, have recognized that the rule's membership requirement is just "another way" of stating that the would-be class representative "must have standing to represent the class," 127 though it need not be an individual member of the class.

Smith v. Board of Education of Morrilton School District No. $32^{128}$ is instructive. In Smith, a teachers association, authorized to sue on behalf of its members, brought a class action under Title VI of the Civil Rights Act of 1964. The defendants moved to dismiss the teachers association's claim on the ground that the association was neither a real party in interest nor a member of the class on behalf of which relief was sought. After holding that the teachers association had standing to sue as a real party in interest, Judge Blackmun rejected the contention that only a class member could be a class representative:

We are not convinced that this standing is to be defeated ... because ... [the association] is not itself, technically, an individual member of a class. Certainly a class action, under Rule 23(a), must be brought by a member of the class . . . .

(or being sued) as associations. See Fed. R. Crv. P. 23.2 ("Actions Relating to Unincorporated Associations").

${ }^{120}$ E.g., Woodworkers v. Georgia Pac. Corp., 568 F.2d 64 (8th Cir. 1977); Schoeppner v. General Tel. Co., 417 F. Supp. 453 (W.D. Pa. 1976); Local 186, Int'l Pulp Workers v. Minnesota Mining \& Mfg. Co., 304 F. Supp. 1284 (N.D. Ind. 1969).

${ }_{121}$ E.g., Rodriguez v. Swank, 318 F. Supp. 289, 294 (N.D. Ill. 1970).

122 E.g., In re Miscellaneous Sec. Litigation, 25 Fed. R. Serv. 2d 733, 737 (E.D.N.Y. 1978); Markewich v. Adikes, 76 F.R.D. 68 (E.D.N.Y. 1978); Seiden v. Nicholson, 69 F.R.D. 681 (N.D. Ill. 1976); Northern Acceptance Trust 1065 v. AMFAC, Inc., 14 Fed. R. Serv. 2d 1372 (D. Hawaii 1971).

${ }^{123}$ E.g., Clark v. Cameron Brown Co,, 72 F.R.D. 48 (M.D.N.C. 1976).

124 E.g., Ernst \& Ernst v. United States Dist. Court, 457 F.2d 1399 (5th Cir. 1972) (since there was some doubt that the bankrupt could have brought this action, a second class representative was added).

${ }^{125}$ E.g., Illinois v. Harper \& Row Publishers, Inc., 301 F. Supp. 484 (N.D. Ill. 1969); Illinois v. Brunswick Corp., 32 F.R.D. 453 (N.D. Ill. 1963).

${ }^{123}$ The courts instead focus on whether or not the would-be class representative has, derivatively, standing to raise issues common to the class, and whether or not he can provide adequate representation for the class. See cases collected at notes 121-124 supra.

127 3B Moore's Federal Practice, I 23.04[2], at 23-121 to 23-122 (2d ed. 1979).

123365 F.2d 770 (8th Cir. 1966). 
But to argue that [the association] . . . here is not a member of the class for which relief is sought is, we think, but another way of arguing the question whether [the association] . . . is a real party in interest. . . Having held that [the association] is a proper party in this latter respect, we think it follows that it is not to be dismissed from the case because of Rule 23(a). ${ }^{129}$

This widespread view of the membership language as a standing requirement suggests that rule 23(a)'s "membership" requirement neither is nor ought to be a technical bar to application of rule 23 to EEOC class suits. Congress did make the EEOC a real party in interest; in the words of Senator Javits, Congress has "given permission to the EEOC to be a properly suing party" 130 so that it could "proceed by class suit."131 Moreover, the argument that there is "no more compelling reason to excuse the EEOC from satisfying rule 23's membership requirement than can be found for excusing compliance with all of rule 23's requirements"132 is ill-considered. The principal reason Congress opted for court enforcement by the Commission, and not cease-and-desist power, was precisely to provide the procedural protections of a judicial proceeding under the Federal Rules of Civil Procedure. ${ }^{133}$ The restrictive view of the membership requirement serves only to deny defendants and aggrieved parties that protection, since courts that adhere to that view nevertheless allow the EEOC to bring class suits without rule 23 certification. Acknowledging that the EEOC has standing to bring class suits and therefore satisfies the membership requirement would eliminate this anomoly and ensure that its enforcement actions conform to normal procedural standards.

i2 Id. at 777 (citations omitted). The Second Circuit adopted a similar position in Norwalk CORE v. Norwalk Redev. Auth., 395 F.2d 920 (2d Cir. 1968). Three associations brought a class action alleging discrimination in an urban renewal project. The district court had held that the associations were "not themselves members of the classes whose rights they claim to be asserting." Id. at 937 (quoting Norwalk CORE v. Norwalk Redev. Auth., 42 F.R.D. 617, 622 (D. Conn. 1967)). In reversing the district court on this point, the Second Circuit said: "We think that the reasons for requiring an individual plaintiff in a class action to be a member of the class do not necessarily preclude an association from representing a class where its raison d'etre is to represent the interests of that class." Id. The Whirlpool court dismissed these cases as inapposite, stating that they "dealt with the issue of standing rather than . . . that of class membership under Rule 23." EEOC v. Whirlpool Corp., 80 F.R.D. 10, 18 (N.D. Ind. 1978). Although these cases dealt with standing, they did so in terms of the membership requirement of rule 23 .

${ }^{330} 118$ Cong. REC. 4082 (1972), reprinted in 1972 LEgiSLATIVE HistoRY, supra note 23, at 1590.

i31 Id., reprinted in 1972 Legislative HistoRy, supra note 23 , at 1589.

132 EEOC v. Akron Nat'l Bank \& Trust Co., 78 F.R.D. 684, 687 (N.D. Ohio 1978).

${ }^{33}$ See text and note at note 64 supra. 


\section{B. Adequacy of Representation Requirement}

Class certification under rule 23 is possible only if the representative party "will fairly and adequately protect the interests of the class." 134 Some courts have concluded that "as a matter of law" the EEOC can never satisfy this requirement because it must always prefer the public interest over private interests in its class suits. ${ }^{135}$ As discussed above, the Commission has no such transcendent obligation to the public interest. The Act was fashioned to serve the public interest through enforcement of the rights of aggrieved parties. Although subsequent cases have in fact shown that the EEOC may be more concerned with future compliance than with obtaining back pay for aggrieved individuals, ${ }^{136}$ this conflict should not disqualify the EEOC as a class representative.

First, the EEOC's conflict of interest is not unique to class actions. It may occur in actions for relief only for charging parties. ${ }^{137}$ Since Congress clearly intended the EEOC to represent private parties despite these conflicts, there is no sound reason to hold the EEOC an inadequate class representative because of these conflicts. Furthermore, Congress provided the appropriate safeguard within Title VII itself by specifying that adequacy of representation problems be resolved, not by separate actions, but by intervention of aggrieved individuals in the EEOC's suit. ${ }^{138}$ Class-action certification provides related protections in EEOC class suits by increasing judicial control of the proceedings and permitting some form of informal notice ${ }^{139}$ of the pendency of the action and their right to intervene.

134 Fed. R. Crv. P. 23(a).

${ }^{135}$ See, e.g., EEOC v. Akron Nat'l Bank \& Trust Co., 78 F.R.D. 684, 687 (N.D. Ohio 1978).

${ }^{136}$ See McClain v. Wagner Elec. Corp., 550 F.2d 1115 (8th Cir. 1977).

${ }^{137}$ In McClain, for example, the EEOC had previously sued on the basis of several charges, without notifying the charging parties of the fact that a suit had been instituted. Their statutory right to intervene was, of course, worthless without such notice. Although the suit was not a class action, the EEOC settled the suit for only injunctive relief. McClain, one of the charging parties, brought a subsequent suit to recover back pay. The Eighth Circuit held that a charging party was limited to his statutory right to intervene in an EEOC suit and could not sue after an EEOC suit on his behalf. Id. at 1121.

138 Act of $1972, \S 706(f)(1), 42$ U.S.C. $\S 2000 \mathrm{e}-5(\mathrm{f})(1)(1976)$.

${ }^{130}$ Most EEOC class actions will be certified as (b)(2) actions, since injunctive, as well as monetary, relief is requested. Formal rule 23 notice will not, therefore, be necessary even if the class is certified under rule 23. See, e.g., Wetzel v. Liberty Mutual Ins. Co., 508 F.2d 239 (3d Cir.) (notice not required in combined (b)(2)-(b)(3) class action), cert. denied, 421 U.S. 972 (1975). Notice on the employee bulletin board will be sufficient for most members of most classes-although some additional notice to nonemployees may be necessary. Since most persons who were illegally fired or denied employment should be identifiable from the defendant's records, notice to such persons would not, usually, be unduly burdensome. More- 
Second, no court has indicated that the EEOC is an inadequate litigator of the claims of aggrieved individuals. Indeed, as the Fifth Circuit pointed out in Holmes, with its "resources, experience and tenacity," one would normally expect the EEOC to be the "representative par excellence"-and it is "certainly as likely a candidate as any to satisfy $23(\mathrm{a})(4) .{ }^{.140}$ Even the Ninth Circuit, holding the EEOC exempt from rule 23, stated that "Congress has already made the determination that the EEOC is an adequate representative of the victims of employment discrimination." 141

Finally, the only specific conflict of interest identified by the district courts goes to the question of adequacy in settlement, not litigation. ${ }^{12}$ Upon close examination, however, the EEOC's possible conflicts of interest in settlement, although different from those of the typical class representative, do not appear to be any worse. ${ }^{143}$ The Commission may prefer future affirmative action to injunctive or monetary relief running to the class. A private class representative may prefer that the settlement provide more injunctive or monetary relief for himself than for other members of the class. The EEOC may prefer settlement to full litigation in order to preserve scarce agency resources. The attorney for a private plaintiff may prefer a settlement providing generous payments of attorney's fees accrued to date over full litigation in which he might recover less-or even nothing-per hour expended.

Perhaps the most compelling reason for concluding that the EEOC is an adequate representative is that its identifiable conflicts of interest are in the very area in which rule 23 expects conflicts and provides appropriate protection: a class action cannot be settled or

over, if they are to receive back pay, it will eventually be necessary to identify them and request that they submit their claims. In a recent case, the Fifth Circuit became the first circuit to require notice in a combined (b)(2)-(b)(3) class action. Johnson v. General Motors Corp., 20 Fair Empl. Prac. Cas. 239 (5th Cir. 1979). The court did, however, note that such notice need not always "be equivalent to that required in (b)(3) actions." Id. at 243.

140556 F.2d at 797.

14 EEOC v. General Tel. Co., 20 Fair Empl. Prac. Cas. 52, 55 (9th Cir. 1979).

142 McClain v. Wagner Elec. Corp., 550 F.2d 1115 (8th Cir. 1977) (conflict of interest in settlement); EEOC v. Whirlpool Corp., 80 F.R.D. 10, 14 (N.D. Ind. 1978) (it is difficult to identify precisely the rationale of the Whirlpool court, but the case cited raises conflict of interest in settlement); EEOC v. Akron Nat'l Bank \& Trust Co., 78 F.R.D. 684, 688 (N.D. Ohio 1978) (no specific conflict identified); EEOC v. General Tel. Co., 16 Fair Empl. Prac. Cas. 476, 479 (W.D. Wash. 1977) (conflict of interest in settlement), aff'd, 20 Fair Empl. Prac. Cas. 52 (9th Cir. 1979).

its Adequate representation does not require identity of interests-"[a] conflict that will prevent a plaintiff from meeting the $23(\mathrm{a})(4)$ prerequisite must be fundamental; it must go to the heart of the litigation." $4 \mathrm{H}$. NEWBURG, supra note $52, \S 7518 \mathrm{c}$, at 19 . See also 3B Moore's Federal Practice Tf 23.07[2], at 23-221 (2d ed. 1979). 
compromised without court approval and notice to the class. The adequate-representation requirement should not, therefore, preclude certification in EEOC actions. ${ }^{144}$ The incongruity created by courts that hold otherwise is indisputable: the EEOC is unable to serve as an adequate class representative because of conflicts of interest with the class, yet it is permitted to bring class suits without the application of the very rule 23 procedures that would resolve those conflicts.

14 Unlike the membership and adequate-representation requirements, the numerosity, commonality, and typicality requirements of rule $23(\mathrm{a})$ raise no unique issues in EEOC suits. Typicality requires, not identity of claims, but rather a sufficient nexus between the claims of class members and the representative to warrant class action treatment, Millenson, Title VII Class Actions, in I Equal Employment Practice Guide, at III-5 (J. Erickson \& K. McGovern eds. 1979). In EEOC v. General Tel. Co., 20 Fair Empl. Prac. Cas. 52 (9th Cir. 1979), the Ninth Circuit stated that the EEOC does not satisfy the typicality requirement of rule 23 because it sues "to vindicate the public interest." Id. at 55 . The Ninth Circuit failed to appreciate that, regardless of the EEOC's purpose in bringing suit, it asserts the claims of absent aggrieved individuals when it sues. The Commission's claims are not only typical of the claims of the class-they are identical to the claims of the class.

A question of law or fact must be common to the class in order to meet the commonality requirement. In EEOC suits, the question is simply whether questions of law or fact are common to the class whose claims the EEOC is asserting.

The numerosity requirement of rule $23(\mathrm{a})$ is met if "the class is so numerous that joinder of all members is impracticable." Fed. R. Crv. P. 23(a)(1). The Whirlpool court stated that application of ruile 23 , with its "numerosity requirement" would foreclose EEOC suits for small classes. 80 F.R.D. at 19. The court apparently reasoned that if section 706 EEOC suits were under rule 23, the EEOC could not represent any one other than charging parties unless a rule 23 class action could be brought. See id. This is not, however, a real problem. If the size of the class precludes joinder under rule 23 , then joinder under rule 19 or 20 is appropriate-the EEOC need only name those on whose behalf and with whose permission it sues. See, e.g., EEOC v. Datapoint Corp., 12 Fair Empl. Prac. Cas. 1133, 1134 (W.D. Tex. 1975), aff'd, 570 F.2d 1264 (5th Cir. 1978).

It could be argued that members of a small "class" cannot be joined unless they have exhausted the appropriate administrative channels (filing a charge, etc.). Since neither absent class members nor intervenors need exhaust administrative procedures, see, e.g., Albe-: marle Paper Co. v. Moody, 422 U.S. 405, 414 n.8 (1975) (class members); Bowe v. ColgatePalmolive Co., 416 F.2d 711, 719 (7th Cir. 1969) (intervenors), those joined in an EEOC action should not be required to do so. This simple solution has been ignored by the commentator favoring application of rule 23 to EEOC suits. Bumpass, supra note 14, at 377-80. This commentator instead accepts the Whirlpool court's analysis of the problem, but argues that the problem is not very serious since (1) the court can appoint private attorneys to represent noncharging members of a class that is too small to be certified; (2) if the claims were too small to warrant private attorneys, the suit would not be an efficient use of the EEOC's resources; (3) the EEOC can seek injunctive relief without joinder; (4) relatively small classes have been certified; (5) courts have considered factors other than pure numbers relevant to the question of "impracticability of joinder." Such restraint on the EEOC's ability to represent small groups is, however, contrary to congressional intent. Congress intended the EEOC to handle most claims, and the private right of action was retained to allow individuals to escape the morass of agency delay. See text and note at note 95 supra. 


\section{Protecting Aggrieved Persons and Defrendants Through Class Certification}

Rule 23 certification plays a central protective role in representative actions. First, it is a necessary joinder device. ${ }^{145}$ Although the rule states that an action "may" be maintained as a class action if the prerequisites of rule $23(\mathrm{c})$ and the requirements of subsections (b)(1), (b)(2), or (b)(3) are satisfied, certification is not always optional. Where rule 19 requires joinder of persons needed for a just adjudication, class certification may be necessary if the absent parties are too numerous to be joined. ${ }^{146}$ This function of rule 23 has long been recognized, ${ }^{147}$ although the courts have not appreciated its importance in EEOC class suits.

In addition to its formal joinder function, rule 23 serves a number of protective functions. Principally, it is designed to ensure that absent parties receive due process through increased court control of proceedings ${ }^{148}$ and settlements. ${ }^{149}$ Certification of a class action

its Historically, class actions developed as a necessary joinder device to handle cases in which joinder of all parties interested in the action was impracticable. It was later extended to include voluntary joinder of a large number of persons. Kaplan, 1966 Amendments of the Federal Rules of Civil Procedure (pt. 1), 81 HARv. L. REv. 356, 375-76 (1967).

"' Rule 19 sets standards for joinder of persons needed for a just adjudication:

[A] person who . . . [can be joined] shall be joined as a party in the action if . . . (2) he claims an interest relating to the subject of the action and is so situated that the disposition of the action in his absence may (i) as a practical matter impair or impede his ability to protect that interest or (ii) leave any of the persons already parties subject to a substantial risk of incurring double, multiple, or otherwise inconsistent obligations by reason of his claimed interest.

The first and third criteria of rule 23(b)(1) are equivalent to these criteria.

Since class actions first developed as a necessary joinder device, the close relationship between rules 19 and 23 is not surprising-nor, as the Advisory Committee Notes point out, is it accidental. Fed. R. Crv. P., Adv. Comm. Notes, 39 F.R.D. 69, 100 (1966). The Committee described the necessity for class actions in terms of the policies of rule 19:

The felt necessity for a class action is greatest when the courts are called upon to order or sanction an alteration of the status quo in circumstances such that a large number of persons are in a position to call on a single person to alter the status quo, or to complain if it is altered, and the possibility exists that [the] actor may be called on to act in inconsistent ways.

Id. (quoting D. Louisell \& G. Hazard, Cases and Materials on Pleading and Procedure: STATE AND FEDERAL 719 (1962)). It went on to state: "In various situations an adjudication as to one or more members of the class will necessarily have an adverse practical effect on the interests of other members who should therefore be represented in the lawsuit." Id. at 101. Since rule 23 is appropriate in these circumstances to protect the defendant or absent persons, and since necessary joinder is not voluntary, it follows that when a class may be certified under the first and third criteria of rule $23(\mathrm{~b})(1)$, it must be certified, whether or not the plaintiff desires to bring a class action.

117 See, e.g., Supreme Tribe of Ben-Hur v. Cauble, 225 U.S. 356, 366-67 (1921). See also 3B Moore's Federal Practice Tf 23.35[2], at 23-276 (2d ed. 1979).

${ }_{148}$ See Dolgow v. Anderson, 43 F.R.D. 472, 481 (E.D. N.Y. 1968); C. WRIGHT, HaNDBOOK OF THE LAW OF THE FEDERAL CoURTS, $\$ 72$, at 357 (3d ed. 1976). Rule 23(d) gives the court a variety of discretionary powers which may be used to achieve this end: 
promotes these ends by alerting the court to "the full implications of recognizing rights or remedies." 150 This heuristic ${ }^{151}$ function enhances the enforcement of the relevant substantive rights in the action. Moreover, certification ensures that defendants will have res judicata protection against those whose rights are adjudicated in a class suit. ${ }^{152}$

Even prior to class certification, courts are careful to avoid prejudice to putative class members in class actions: the filing of the class action may toll the statute of limitations for class members, ${ }^{153}$ and notice may be required if the class action is dismissed or compromised prior to certification. ${ }^{154}$ Without such protections, absent class members may rely, to their detriment, on the assertion of their claims by the would-be representative.

Class definition, required by rule 23 at an early stage of the proceeding, protects both putative class members and defendants. Without class definition, putative class members might rely on what they think is an action on their behalf, only to discover too late that they are not included in the class. Class definition provides defendants with information needed to prepare their defense, and alerts both plaintiffs and defendants to the conclusive impact of the action.

Rule 23 thus provides a framework designed to ensure procedural fairness to both class members, who will be bound by the representative action, and defendants, who may be found liable to a large number of people. In deciding whether rule 23 should be

In the conduct of actions to which this rule applies, the court may make appropriate orders: (1) determining the course of proceedings or prescribing measures to prevent undue repetition or complication in the presentation of evidence or argument; (2) requiring, for the protection of the members of the class or otherwise for the fair conduct of the action, that notice be given in such manner as the court may direct to some or all of the members of any step in the action, or of the proposed extent of the judgment, or of the opportunity of members to signify whether they consider the representation fair and adequate, to intervene and present claims or defenses, or otherwise to come into the action; (3) imposing conditions on the representative parties or on intervenors; (4) requiring that the pleadings be amended to eliminate therefrom allegations as to representation of absent persons, and that the action proceed accordingly; (5) dealing with similar procedural matters. The orders may be combined with an order under Rule 16, and may be altered or amended as may be desirable from time to time.

14 Developments in the Law-Class Actions, 89 HARv. L. Rev. 1318, 1536 (1976).

${ }^{150}$ Id. at $1353,1432-33$.

151 Id. at 1366.

152 See, e.g., EEOC v. Data Point Corp., 570 F.2d 1264 (5th Cir. 1978).

153 American Pipe \& Constr. Co. v. Utah, 414 U.S. 538, 552-53 (1974).

${ }^{154}$ See, e.g., Shelton v. Pargo, Inc., 19 Fair Empl. Prac. Cas. 39 (W.D.N.C. 1979) (notice of precertification settlement ordered sent to putative class member); Developments in the Law-Class Actions, supra note 149, at 1541, and cases cited therein. 
applied to EEOC suits, it is necessary to consider the functions of the rule in terms of the relevant interests of absent aggrieved individuals and defendants.

\section{A. Aggrieved Individuals}

1. The Need for Joinder. EEOC class suits have a potentially broad impact on the ability of aggrieved individuals to protect their interests. In the first place, injunctive relief obtained in an EEOC suit or consent decree under either section 706 or section 707 may affect the relief available to aggrieved individuals in a subsequent suit. Courts are reluctant to order injunctive relief that duplicates or is inconsistent with that obtained by the EEOC. ${ }^{155}$ Class members may desire duplicate injunctions because of the possibility of "inadequate EEOC enforcement of its decree and the uncertain ability of a nonparty to enforce a decree even if the nonparty is clearly an intended beneficiary." 156 Since EEOC enforcement review procedures are often not followed, ${ }^{157}$ such concern is not unfounded.

Furthermore, many injunctions obtained by the EEOC are such that aggrieved individuals are likely to desire inconsistent injunctions. If, for example, the relief obtained by the Commission includes detailed changes to a seniority system, it is likely that at least some absent aggrieved individuals would prefer changes that give them more seniority than they had received under the EEOC plan. ${ }^{158}$. The need for joinder in this situation is highlighted if one considers that, as Professor Moore has pointed out, "distribution of internal ranks are in effect an allocation of a limited fund in which preference for one is discrimination against another." 159

Regardless whether full relief is available to aggrieved individuals in a subsequent proceeding, they may be prejudiced by relying on the EEOC's assertion of their claims for either injunctive or

${ }_{135}$ See United States v. City of Jackson, 519 F.2d 1147, 1152 n.10 (5th Cir. 1975) (courts try to avoid overlapping or conflicting injunctions); Leisner v. New York Tel. Co., 358 F. Supp. 359, 369-70 (S.D.N.Y. 1973) (although class is not in privity with EEOC consent decree, court will refuse to grant relief which duplicates, or is in conflict with, EEOC's consent decree).

134 Sullivan, supra note 40, at 525 n.202.

137 See Comptroller General's REPORT, supra note 44, at 51-53.

138 For a partial list of the cases in which private plaintiffs have attempted to bring class actions against AT\&T subsidiaries after the EEOC's settlement with AT\&T, see Walker v. Southwestern Bell Tel. Co., 18 Fair Empl. Prac. Cas. 1784, 1786 (N.D. Tex. 1978) (class certification denied because of consent decree) and cases cited therein.

153 3B MoORE's FEDERAL PrActice If 23.40[3], at 23-299 n.15 (2d ed. 1979). 
monetary relief in actions under section 706 or section 707 . Such reliance may take several forms. A class member, knowing that the EEOC is suing for classwide relief, may not file a charge with the Commission when he would otherwise do so. Since a charge must be filed within 180 days of the unlawful employment practice, ${ }^{160}$ it may be too late for him to file a charge after he learns of the EEOC's settlement. A class member, receiving his right-to-sue notice during the pendency of the EEOC's suit, may fail to sue, relying on the EEOC's assertion of his claim. If the Commission settles more than 90 days thereafter, it will be too late for the class member to sue.

This problem is exacerbated by the fact that the EEOC currently determines "the nature and extent of the class during discovery" and "maintains great flexibility throughout the lawsuit in determining what employees will be entitled to benefit from a decree in the government's favor." 161 Class members may reasonably rely on the EEOC's assertion of their claim only to discover later-when it may be too late for them to sue-that they are not included in the recovery. Thus, class definition itself provides class members with a safeguard necessary in EEOC suits: it enables them to determine whether or not the Commission intends to assert their claims.

The real danger that uncertified EEOC class suits may harm private interests is highlighted by the refusal of some courts to certify class actions brought by aggrieved individuals when an EEOC suit is pending ${ }^{162}$ or has been settled by a consent decree. ${ }^{163}$ If individuals are unable to bring class actions after the EEOC has filed suit or obtained a consent decree, putative class members are, in effect, limited by the results of the EEOC action. Not only will such individuals be unable to obtain duplicate or inconsistent injunctive relief, their recovery of back pay will be limited to that obtained by the Commission.

${ }^{180}$ Act of $1972, \S 706(e), 42$ U.S.C. $\$ 2000 \mathrm{e}-5(\mathrm{e})(1976)$.

181 EEOC v. Delaware Trust Co., 18 Fair Empl. Prac. Cas. 1521, 1523 (D. Del. 1979) (the court reported EEOC's description of its procedure).

162 See, e.g., Franklin v. General Elec. Co., 15 Fair Empl. Prac. Cas. 1085, 1086 (W.D. Va. 1975); Stuart v. Hewlett-Packard Co., 66 F.R.D. 73 (E.D. Mich. 1975). Cf. Burlington N. Inc. v. EEOC, 582 F.2d 1097 (7th Cir. 1978) (seemingly approving district court denials of class certification when EEOC has suit for broad relief pending); United States v. United States Steel Corp., 520 F.2d 1043, 1047 (5th Cir. 1975) (classes kept small while government present in suit; when government withdrew because of settlement, lower court willing to expand class).

${ }^{183}$ E.g., Walker v. Southwestern Bell Tel. Co., 18 Fair Empl. Prac. Cas. 1784 (N.D. Tex. 1978); Garnett v. Mountain States Tel. \& Tel. Co., 18 Fair Empl. Prac. Cas. 1773 (D. Colo. 1978); Peals v. Southwestern Bell Tel. Co., 18 Fair Empl. Prac. Cas. 1781 (D. Kan. 1977); Butera v. Mountain States Tel. \& Tel. Co., 18 Fair Empl. Prac. Cas. 1779 (D. Colo. 1977); LaCombe v. Mountain States Tel. \& Tel. Co., 18 Fair Empl. Prac. Cas. 1774 (D. Colo. 1977). 
Since aggrieved individuals may effectively be bound by the outcome of an EEOC action under either section 706 or section 707, there can be no doubt that they are persons to be joined under the lower standard of rule 19(a): the EEOC action in their absence "may as a practical matter impair or impede" their ability to protect their interests. Rule 23 certification is, therefore, necessary if the EEOC sues on behalf of aggrieved individuals too numerous to join.

It could be argued that, since Congress did not require charging parties to be joined pursuant to rule 19 when the EEOC brings a section 706 action on behalf of specific charging parties, it is anomalous to require joinder through rule 23 in EEOC class suits. This misses the point, however. Joinder is essential to ensure that absent persons will not be prejudiced by the suit. Congress was careful to protect that interest when it indicated that the Commission should give notice of suit to charging parties and allowed charging parties to intervene. ${ }^{164}$ Equivalent protections are not present when the EEOC brings class actions unless certification is required. The EEOC is generally recalcitrant about establishing the contours of the class early in litigation, thus making effective notice difficult and intervention nearly impossible. Moreover, unless the class is certified, it is not at all clear that absent persons, other than charging parties, would have any right to intervene. If the EEOC is viewed as suing for the public interest, absent class members may be viewed, not as parties with a right to intervene, but as a disruptive force in the litigation. Finally, if the class is large, intervention of all persons affected by the action may be impossible.

2. Ensuring the Fairness of Class Suits. The framework of procedural safeguards provided by rule 23 also presents significant reasons for demanding that EEOC class suits be certified as class actions. Court control of proceedings is appropriate in EEOC suits under section 706 or section 707, as it is in other representative actions, because all affected persons are not present. Indeed, since there may not be a single aggrieved individual present, such control seems especially appropriate. The heuristic function of court control-calling the court's attention to the interests of individuals who are not before the court but will be affected by the action-is appropriate in any Title VII class action. There will often be conflicts within the class as to proper allocation of the limited number of jobs 
and seniority positions. ${ }^{165}$ The more fully the court appreciates the variety of interests within the class, the more likely it is that the court will be able to order appropriate relief for absent aggrieved individuals.

Court control of settlement ${ }^{166}$ is also desirable. The EEOC has used the claims of aggrieved individuals, to their possible detriment, to leverage its bargaining position in suits brought under both section 706 and section 707 . As the Fifth Circuit pointed out in Holmes, the rule 23 protections designed "to check possible abuse of the class action device" are "compelling regardless of the identity of the plaintiff."'167

The discretionary powers given the court by rule $23(\mathrm{~d})$ include the ability to send informal notice ${ }^{188}$ to class members and request intervention. Rule $23(\mathrm{~d})$ provides a mechanism whereby the court can involve aggrieved individuals with varying interests in the settlement negotiations, ${ }^{169}$ thus increasing the chances of achieving a settlement which is just and equitable to all members of the class. The discretionary, informal notice of rule 23(d) can also be used to ensure that the statutory right of intervention, given by Congress to aggrieved individuals, is meaningful in every EEOC action.

If rule 23 is applied to EEOC suits, the statute of limitations will toll, at least in some circumstances, for putative class members at the time the complaint is filed. ${ }^{170}$ If such a complaint is subsequently dismissed or compromised prior to class certification, suits by aggrieved individuals who may have relied on the Commission's assertion of their claims will not be barred. If appropriate, the court will also order notice to absent putative class members, informing them of the termination of a suit upon which they may have relied. Thus, class certification is necessary to ensure adequate protection of the interests of absent persons, to meet the requirement that persons who will be adversely affected by an action are joined, and to improve the quality of relief given to those whose rights are adjudicated in the action.

${ }_{165}$ 'See, e.g., Lewis v. Phillip Morris, Inc., 419 F. Supp. 345, 352 (D. Va. 1976).

${ }^{166}$ See Fed. R. Crv. P. 23(e) ("A class action shall not be dismissed or compromised without the approval of the court, and notice of the proposed dismissal or compromise shall be given to all members of the class in such manner as the court directs.").

${ }^{167} 556$ F.2d at 795.96.

${ }^{168}$ For example, on the company bulletin board.

${ }^{36}$ The Civil Rights Commission has severely criticized the EEOC for its failure to involve aggrieved individuals in settlement negotiations. CIVL RIGHTS COMMISSION REPORT, supra note 144 , at 646 .

${ }^{170}$ American Pipe \& Constr. Co., 414 U.S. 538, 552-53 (1974). 


\section{B. Defendants}

1. The Need for Joinder. The joinder function of rule 23 is of particular importance to defendants. EEOC actions will often involve situations in which the failure to join absent individuals opens defendants to the risk of multiple litigation. Joinder becomes necessary, either because "complete relief cannot be accorded among those already parties" 171 or because the absence of aggrieved individuals will subject the defendant to a substantial risk of future inconsistent liability. Since EEOC class suits may involve persons too numerous to join, rule 23 certification may be necessary to ensure that the required parties are bound by the action.

Although complete relief can generally be given the EEOC without joinder of aggrieved individuals, the defendant is not in a similar situation. Absent aggrieved individuals will not be bound by the EEOC action. ${ }^{172}$ Thus, unless rule 23 certification is required, defendants will be open to "repeated lawsuits on the same essential subject matter." 173 Moreover, since the Commission typically seeks detailed injunctive relief, ${ }^{174}$ and since aggrieved individuals frequently desire different injunctive relief, ${ }^{175}$ the defendant in EEOC suits under either enforcement section is left subject to some risk of future inconsistent adjudications. ${ }^{176}$ Joinder of absent aggrieved in-

171 FED. R. CIV. P. 19(a)(1).

172 See, e.g., United States v. Allegheny-Ludlum Indus., Inc., 517 F.2d 826, 845 (5th Cir. 1975), cert. denied, 425 U.S. 944 (1976); Rodriguez v. East Tex. Motor Freight, Inc., 505 F.2d 40, 65 (5th Cir. 1974), rev'd on other grounds, 431 U.S. 395 (1977); Williamson v. Bethlehem Steel Corp., 468 F.2d 1201, 1203-04 (2d Cir. 1972), cert. denied, 411 U.S. 931 (1973).

${ }^{173}$ Fed. R. Crv. P., Adv. Comm. Notes, 39 F.R.D. 69, 91 (1966). The Holmes, Datapoint, and Delaware Trust courts noted that rule 23 was needed to protect the defendant from multiple lawsuits on the same claims. EEOC v. D.H. Holmes Co., 556 F.2d 787, 795 (5th Cir. 1977), cert. denied, 436 U.S. 962 (1978); EEOC v. Datapoint Corp., 570 F.2d 1264 (5th Cir. 1978); EEOC v. Delaware Trust Co., 18 Fair Empl. Prac. Cas. 1521 (D. Del. 1979). Contra, EEOC v. General Tel. Co., 20 Fair Empl. Prac. Cas. 52, 60 (9th Cir. 1979) (defendants can be protected from repeated lawsuits without rule 23 certification). For a discussion of the General Telephone solution, see note 215 infra.

174 See, for example, the consent decree filed in the AT\&T settlement. EEOC v. AT\&T, Civ. No. 73-149 (E. D. Pa., filed Jan. 18, 1973), reprinted in Equal EMployment Opportunity AND THE AT\&T CASE, 283-96 (P. Wallace ed. 1976).

${ }_{175}$ Individuals have sued various AT\&T subsidiaries (all of whom were parties to the settlement) after the settlement. See, e.g., Walker v. Southwestern Bell Tel. Co., 18 Fair Empl. Prac. Cas. 1784 (N.D. Tex. 1978); Garnett v. Mountain States Tel. \& Tel. Co., 18 Fair Empl. Prac. Cas. 1773 (D. Colo. 1978); Peals v. Southwestern Bell Tel. Co., 18 Fair Empl. Prac. Cas. 1781 (D. Kan. 1977); Butera v. Mountain States Tel. \& Tel. Co., 18 Fair Empl. Prac. Cas. 1779 (D. Colo. 1977); LaCombe v. Mountain States Tel. \& Tel. Co., 18 Fair Empl. Prac. Cas. 1774 (D. Colo. 1977).

i7 To the extent that subsequent, inconsistent relief is precluded, aggrieved individuals, rather than defendants, may be prejudiced by the EEOC action in their absence. In either event, joinder is appropriate. 
dividuals is, therefore, appropriate in any EEOC suit under the standard of rule 19(a)(2)(ii) ${ }^{177}$ as well as the standard of rule 19(a)(1). ${ }^{178}$ If such persons are too numerous to join, rule 23 is the appropriate joinder device.

2. Procedural Fairness for Defendants. If rule 23 is used to join absent aggrieved individuals, defendants will receive res judicata protection. The drafters of the 1966 amendments to rule 23 considered such protection a necessary part of procedural fairness to defendants in class action suits: since defendants will be subject to classwide liability if they lose, fairness requires that the class be bound by the outcome if the defendant wins. ${ }^{179}$ As several courts have pointed out, such protection is appropriate in any EEOC suit. ${ }^{180}$

The EEOC has argued that private persons should not be bound by a government enforcement suit. ${ }^{181}$ This principle is inappropriate in EEOC litigation for two reasons. First, rule 23 provides important protections for absent class members. These protections, when combined with the right to intervene, promote fairness to the absent parties. Second, it is no more unfair to hold aggrieved indi-

${ }^{177}$ FED. R. Crv. P. 19(a)(2)(ii) (joinder appropriate to protect parties from "risk of double, multiple, or otherwise inconsistent obligations").

An example of a typical application of rule 19(a)(ii) is a suit by a union seeking a declaratory judgment that certain jobs belong, under the terms of its contract with the defendant, to its members. If a second union contends that the same jobs belong to its members, joinder is appropriate to protect the defendant from the risk of being ordered to award the same jobs to two different unions. EEOC suits for injunctive relief are analogous; the defendant may be ordered to award the same slots in its seniority system to two different sets of individuals: those specified in the EEOC decree and those specified in a subsequent decree obtained by aggrieved individuals.

178 FED. R. Crv. P. 19(a)(1) (joinder appropriate if necessary to accord "complete relief among those already parties").

170 See FED. R. Crv. P., Adv. Comm. Notes, 39 F.R.D. 69, 99 (1966).

180 See, e.g., EEOC v. Datapoint Corp., 570 F.2d 1264, 1268 (5th Cir. 1978); EEOC v. Delaware Trust Co., 18 Fair Empl. Prac. Cas. 1521, 1524 (D. Del. 1979); EEOC v. Page Eng'r, 17 Fair Empl. Prac. Cas. 1638, 1639 (N.D. Ill. 1978). It could be argued, however, that since mutuality is no longer a requirement for assertion of a previous judgment as collateral estoppel in a subsequent suit, see generally RESTATEMENT (SECOND) of JUDGMENTs $\$ 88$, at 89-92 (Tent. Draft No. 2, 1975), there is no reason why defendants in EEOC suits should be given special res judicata protection. If the EEOC asserts classwide claims and wins, however, aggrieved individuals will not assert the prior judgment in a subsequent suit; they will benefit directly from the EEOC suit, but will be free to relitigate the same claims in the event the EEOC loses. When a nonparty is allowed to assert the outcome of a prior action against a defendant, on the other hand, the same claim-monetary or otherwise-is not at stake in both actions. A judgment for the defendant in the first action would, at least, have been binding as to that claim. The demise of the absolute mutuality requirement for collateral estoppel has not changed the fact that the direct beneficiaries of an action-those whose claims are litigated in the action-are bound by its outcome.

181 See, e.g, EEOC v. Datapoint Corp., 570 F.2d 1264, 1268 (5th Cir. 1978). 
viduals bound by an EEOC suit than it is to hold them bound by a suit by another aggrieved individual. Rule 23 was designed as "a ready and fair means of achieving unitary adjudication in a representative action." 182 There is no more compelling reason for loosening the binding effects of a class suit when the EEOC sues than when private parties act as representatives. Indeed, it would be unfair to defendants to bind them to an outcome in a representative suit mandating relief for absent parties but not to give them the benefit of an adjudication in their favor. Nevertheless, several arguments have been advanced that suggest that such protection for defendants is unnecessary.

The Whirlpool court reasoned that defendants do not need the res judicata protection of rule 23 in Title VII suits because it is unlikely that class members will sue after the EEOC has lost. ${ }^{183}$ EEOC suits will, however, often be followed by private actions. Many class actions for monetary damages are settled; EEOC suits for classwide monetary relief are no exception. Class certification binds class members to a settlement. Currently, defendants have no such protection. EEOC settlements which are seen as unsatisfactory by class members can serve as a catalyst to multiple private suits. ${ }^{184}$ If the EEOC actions had been certified under rule 23 , absent class members, instead of initiating multiple private actions, would receive notice of the proposed settlement and would be able to object in the main action. ${ }^{185}$ Furthermore, when the facts are sufficiently ambiguous, the decision of one court will not deter other actions in other courts. This is especially true in areas, such as Title VII, in which more than one type of evidence may be used to prove the same unlawful act-for example, statistical proof or proof of individual instances of discrimination. Defendants in Title VII actions

${ }_{182}$ EEOC v. Page Eng'r, 17 Fair Empl. Prac. Cas. 1638, 1639 (N.D. Ill. 1978).

185 EEOC v. Whirlpool Corp., 80 F.R.D. 10, 21 (N.D. Ind. 1978).

is See Zimmer \& Sullivan, Consent Decree Settlements by Administrative Agencies in Antitrust and Employment Discrimination: Optimizing Public and Private Interests, 1976 DUKE L.J. 163, 207 n.136:

For example, an EEOC acceptance of the settlement in its pattern or practice suit. against the steel industry, if it is generally perceived to be inadequate, may trigger a number of private actions against different companies, plants, departments, or lines of progression. Although the Commission may have saved itself extensive resources, the consequences could be inefficient in terms of both private plaintiffs and the courts if a multiplicity of suits in different districts follows. There is good reason to believe that at least substantial dissatisfaction exists, although the extent to which it will be reflected in a multiplicity of private actions is unclear.

For a partial list of cases in which private plaintiffs filed class actions after the AT\&T* settlement, see note 175 supra.

is See note 175 supra. 
therefore need the res judicata protection of rule 23 as much as defendants in any other class action. The Federal Rules of Civil Procedure were amended in 1966 to prevent precisely the type of one-way class suits that the EEOC seeks to bring..$^{186}$

Title VII provides that only persons who have filed charges (or on whose behalf charges have been filed) can sue. The EEOC has argued that since the charging party is bound by an EEOC suit based on his charge under section 706, the defendant is really not in danger of multiple suits. ${ }^{187}$ There are two problems with this approach. First, in section 707 suits based on Commissioner charges, no one in the class is bound. ${ }^{188}$ Second, in a section 706 suit, only those whose charges are used by the Commission as the basis for the suit are bound by the EEOC's action. Hundreds of charges are often pending against large employers. ${ }^{189}$ The EEOC is under no obligation to use them all as the basis for its suit. Furthermore, a charge filed after the termination of an EEOC suit may be used as the basis for back pay liability to the class for whom the EEOC obtained recovery, and for (in part) the same time period, since back pay liability extends to a period commencing two years before the filing of the charge. ${ }^{180}$

Thus, if rule 23 certification is not required in an EEOC suit, there may be class members able to bring class actions for the same relief and the same class, thereafter-especially when the defendant is a large employer. ${ }^{191}$ Moreover, the fact that the complex filing and

${ }^{185}$ See FED. R. Civ. P., Adv. Comm. Notes, 39 F.R.D. 69, 99 (1969).

187 EEOC v. Whirlpool Corp., 80 F.R.D. 10, 21 (N.D. Ind. 1978).

${ }^{188}$ See, e.g., EEOC v. Allegheny-Ludlum Indus., Inc., 517 F.2d 826, 845 (5th Cir. 1975), cert. denied, 425 U.S. 944 (1976).

189 Sears reports that 1,850 charges of discrimination have been filed against it and about fifty private lawsuits are now pending. Wall St. J., Mar. 7, 1979, at 38, col. 3. During fiscal 1974 , the EEOC estimated that there were at least 3,184 charges pending against five nationwide employers-an average of 636 charges per employer. CoMPTROLler GENERAL's REPORT, supra note 44 , at 47.

${ }^{190}$ Act of $1972, \S 706(\mathrm{~g}), 42$ U.S.C. $\S 2000 \mathrm{e}-5(\mathrm{~g})$ (1976).

$19 t$ The EEOC's failure to send timely right-to-sue notices increases the probability of multiple suits beyond what could have been foreseen by Congress. Title VII states that the EEOC will send aggreived individuals notice of their right to sue 180 days after the filing of the charge. Act of 1972, § 706(f)(1), 42 U.S.C. $\S 2000$ e-5(f)(1) (1976). Individuals can then bring suit within the next ninety days. Id. If this provision were followed, all class members who were going to sue individually would probably have had to sue before the EEOC commenced any action. If the EEOC were unusually quick in filing suit, class members would certainly have to sue within the pendency of the action, and the actions could be consolidated. Given Congress's emphasis on achieving procedural fairness for defendants, see text and note at note 64 supra, it does not seem proper to ignore a clear protection specified in the statute. Moreover, the practice often effectively denies complainants an alternative to the lengthy administrative process. See Civil Rights Commission REPORT, supra note 44, at 542, 644. 
timing provisions of Title VII reduce the chance of multiple suits cuts both ways. To the extent that class members actually are unable to sue after an EEOC suit, they (rather than the defendant) may have been prejudiced by the EEOC's assertion of their claims in their absence, and have, at any rate, been left with the EEOC as their sole representative without rule 23 protections.

3. Ensuring the Fairness of Class Suits. In addition to res judicata protection, application of rule 23 will give defendants the advantage of early class definition. Class definition provides a defendant with the information needed to prepare a defense. In the Holmes case, the defendant, a year and a half after the complaint had been filed, still did not know "against whom and on what grounds precisely it must defend itself." ${ }^{192}$ Class definition is often needed in EEOC suits, as the Holmes case illustrates, ${ }^{193}$ because the EEOC maintains great flexibility throughout the litigation regarding who will benefit from the action. Class definition is appropriate in order to freeze issues at an early stage and enable the defendant to prepare his defense.

Some courts have taken the position that the procedures of Title VII provide protection equivalent to class definition. ${ }^{19}$ Title VII requires that the defendant receive notice when a charge is filed. ${ }^{195}$ But, since the scope of an EEOC suit can be much broader than the charge, such notice is no help in preparing a defense. ${ }^{196}$ Without class certification, therefore, the defendant is denied the fundamental res judicata protection normally attending class suits, and may even be unable to ascertain the scope and nature of the plaintiff's charges.

\section{Class Certificátion and Title VII Enforcement}

Although certification of EEOC class suits would benefit both

"12 EEOC v. D.H. Holmes Co., 556 F.2d 787, 796, cert. denied, 436 U.S. 962 (1978).

113 Id., at 796. See also EEOC v. Delaware Trust Co., 18 Fair Empl. Prac. Cas. 1521, 1523 (D. Del. 1979).

'" See, e.g., EEOC v. Whirlpool Corp., 80 F.R.D. 10, 21 (N.D. Ind. 1978); EEOC v. Singer Controls Co., 80 F.R.D. 76,79 (N.D. Ohio 1978).

193 Act of 1972, § 706(b), 42 U.S.C. § $2000 \mathrm{e}-5$ (b) (1976) ("the Commission shall serve a notice of the charge (including the date, place and circumstances of the alleged unlawful employment practice) on such employer . . . within ten days"). This provision has not, however, been enforced by the courts. See, e.g., Chromcraft v. EEOC, 465 F. 2d 745 (5th Cir. 1972). In Chromcraft, the court held that this was reasonable, given the EEOC's backlog and pointed out that delaying notice until the EEOC was ready to sue would minimize chances of retaliation. Id. at 746-48.

116 See, e.g., EEOC v. D.H. Holmes Co., 556 F.2d 787, 796 (5th Cir. 1977), cert. denied, 436 U.S. 962 (1978). 
absent class members and defendants, the prospect that it will adversely affect the Commission's enforcement efforts may continue to deter some courts from applying rule 23 to EEOC suits. Such reluctance might follow from the courts' perception that prudence counsels against imposing any procedural restriction that would inhibit the EEOC's enforcement or conciliation efforts. Upon closer examination, however, fears of disruption of the Title VII enforcement scheme prove to be ill-founded. Requiring EEOC compliance with rule 23 accords with the legislative intent underlying Title VII and will promote more effective enforcement of the rights created by Title VII.

\section{A. Consistency with Congressional Intent}

Two distinct arguments suggest that requiring the EEOC to bring suits on behalf of a class of employees under rule 23 is essential to implement the Title VII enforcement scheme envisaged by Congress. First, although Congress regarded the individual employee's right to relief as paramount, ${ }^{197}$ it hoped that the EEOC-through conciliation or, if necessary, enforcement litigation-would handle most charges. ${ }^{188}$ Congress did not give aggrieved individuals two opportunities to secure relief; ${ }^{189}$ section 706 provides that a

197 See text at note 97 supra.

198 See id.

199 Both the Senate and House versions of the cease-and-desist bills clearly stated that duplicate proceedings were not intended. S. 2515, 92d Cong., 1st Sess. 48 (1971) (as reported from committee June 2, 1971), reprinted in 1972 LEGISLATIVE HISTORY, supra note 23, at 344, 391; H.R. 1746, 92d Cong., 1st Sess. 24 (1971) (as reported from committee June 2, 1971), reprinted in 1972 LegisLative HistoRy, supra note 23 , at 32, 55. Although court enforcement was chosen over cease-and-desist authority, members on both sides of that debate agreed that the issue was one of choosing a fair and effective enforcement method. See text and note at note 64 supra.

Moreover, Senator Williams, in his section-by-section analysis of the final version of the Act, stated that "it is not intended that duplication of proceedings should be allowed." 118 Cong. Rec. 4942 (1972), reprinted in 1972 Legislative History, supra note 23, at 1772. This statement was not included in the final section-by-section analysis; the explanation of section 706(f)(1) was reworded in that final version. Compare id. at 4942, reprinted in 1972 LEGISLATIVE History, supra note 23 , at 1772,1773 , with id. at 7168 , reprinted in LEGISLATIVE History, supra note 23, at 1847. Since court enforcement was perceived by Congress as only an alternative method of enforcement to cease-and-desist proceedings, see note 64 supra, it is unlikely that Congress suddenly, without debate, in a compromise designed to satisfy conservatives, decided to authorize duplicate proceedings.

It is true that some courts have allowed the EEOC to sue, based on an individual charge, after that individual has sued or settled-and have done so on the rationale that it is not clear Congress intended to preclude such duplicate proceedings. E.g., EEOC v. North Hills Passavant Hosp., 544 F.2d 664 (3d Cir. 1976); EEOC v. McLean Trucking Co., 525 F.2d 1007 (6th Cir. 1975); EEOC v. Huttig Sash \& Door Co., 511 F.2d 453 (5th Cir. 1975). Contra, EEOC v. Continental Ojl Co., 548 F.2d 884 (10th Cir. 1975); EEOC v. Missouri P. Ry., 493 
charging party may sue on his own behalf only if the EEOC does not do so. ${ }^{200}$ The private right of action was preserved in the 1972 amendments to enable individual plaintiffs to escape the morass of agency delay. ${ }^{201}$ To the extent that, without EEOC certification, absent class members may sue after settlement or judgment in an EEOC suit, current EEOC practice undermines the efficient, nonduplicative enforcement scheme Congress intended. Without a class-certification requirement, the EEOC does not fulfill its role as an agency in which Title VII enforcement can be consolidated, as Congress intended, but acts instead merely as an additional litigator of claims.

Second, although Congress sought to design an efficient enforcement mechanism under Title VII, it did not intend to do so by sacrificing procedural fairness for either aggrieved individuals or employer-defendants. The EEOC's current practice of seeking classwide relief without the formal prerequisites of rule 23 certification may, however, thwart the interests of both these groups. Congress intended to ensure fairness to aggrieved individuals by providing that they were not bound by the EEOC's settlement of their claims unless the settlement was reached in a judicial proceeding in which they had the right to intervene. ${ }^{202}$ Yet, when the EEOC brings an uncertified class action, obtaining employer compliance with Title VII through court-approved settlements and consent decrees rather than through nonbinding conciliation agreements, the EEOC action will often prejudice the ability of aggrieved individuals to obtain relief. ${ }^{203}$ To make Title VII enforcement fair to defendants, Congress chose judicial enforcement over cease-and-desist

F.2d 71 (8th Cir. 1974). These courts have not, however, allowed truly duplicative proceedings. The EEOC cannot, in the second suit, seek relief for those who were plaintiffs in the first suit-they are bound by the outcome of that action. Such suits are "duplicative" in that they are based on the same charge-but they are not duplicative in the sense that they seek relief for the same beneficiaries. See, e.g., EEOC v. McLean Trucking Co., 525 F.2d 1007, 1010 (6th Cir. 1975); EEOC v. Kimberly-Clark Corp., 511 F.2d 1352, 1361 (6th Cir. 1975); EEOC v. American Express Co., 14 Fair Empl. Prac. Cas. 615, 616 (S.D.N.Y. 1977); EEOC v. Eagle Iron Works, 367 F. Supp. 817, 823-24 (S.D. Iowa 1973). By authorizing the EEOC to sue on the basis of a charge filed by a commissioner, Congress indicated that the EEOC should be able to sue for others even though the charging party has sued or settled. There is, therefore, little reason to require a second charge and another round of investigation and conciliation regarding the same employment practices.

${ }^{200}$ Section 706 provides that if the EEOC does not sue within 180 days, the aggrieved individual can do so within the next 90 days. Act of $1972, \S 706(\mathfrak{f})(1), 42$ U.S.C. $\S 2000 \mathrm{e}-$ $5(\mathfrak{f})(1)(1976)$.

201 See text and note at note 95 supra.

${ }^{202}$ Title VII gives charging parties the right to intervene in EEOC litigation on their behalf. Act of 1972, $\S 706(f)(1), 42$ U.S.C. $\$ 2000 \mathrm{e}-5(f)(1)$ (1976). If the EEOC reaches a prelitigation settlement of a charge, a dissatisfied charging party is free to sue. Id.

${ }^{203}$ See text and notes at notes 155-164 supra. 
authority ${ }^{204}$ and limited aggrieved individuals to seeking relief either individually or through the EEOC, but not both. The protection against duplicative actions is vitiated, however, if absent aggrieved individuals are not bound by EEOC class suits.

Imposing the requirements of rule 23 on EEOC class suits would serve Congress's intent to provide procedural fairness to both plaintiffs and defendants in Title VII litigation. EEOC certification would protect the interests of all aggrieved employees by providing for discretionary, informal notice to absent class members, intervention rights, and judicial control over settlements binding on the class; the res judicata effect of a rule 23 class action protects defendants from multiple suits arising out of the same employment practice. ${ }^{205}$ The result would be an EEOC suit more likely to redress the rights of aggrieved persons and eliminate the need for future suits on the same general claims.

\section{B. Impact on Title VII Enforcement}

1. EEOC Enforcement. Application of rule 23 to EEOC suits will disrupt the Commission's current enforcement procedures in several ways. Most importantly, requiring certification under rule 23 will diminish the EEOC's independence in litigation and settlement. Not only will private parties have increased opportunities to intervene in EEOC suits, but the EEOC will no longer be able to obtain consent decrees simply by filing a complaint and proposed settlement on the same day. If the EEOC can only seek classwide relief as a certified class representative, any EEOC settlement, whether arranged prior to filing a complaint or at a later stage in the litigation, will require court approval and notice to class members. ${ }^{206}$ This notice requirement may, in turn, lead to protracted proceedings in which class members object to the terms of a proposed settlement. Furthermore, the requirements of rule 23 will interfere with the EEOC's ability to define the class at a relatively late stage in the proceedings ${ }^{207}$ and settle for future affirmative action.

Although these limitations on the EEOC's enforcement flexibility can be expected to have an adverse short-term impact on the frequency and number of successful EEOC settlements and judg-

20. See note 64 supra.

205 See text and notes at notes 171-191 supra.

${ }_{206}$ See FED. R. Crv. P. 23(e). The cost of such notice is not likely to be a problem because the settlement can provide for payment by the defendant.

${ }^{207}$ See text and note at note 161 supra. 
ments, their net effect may be a more effective use of agency resources. First, because rule 23 requires notice to class members and judicial approval of any settlement of class claims, the quality of relief obtained as a result of settlement is likely to be higher than in an unsupervised EEOC settlement. Second, because settlement of a rule 23 class action will bind class members, class certification will improve the Commission's bargaining position in settlement negotiations. ${ }^{208}$ Third, class certification would reduce the responsibilities of the EEOC in monitoring employer compliance with settlement terms, since consent decrees entered in settlement of a class action will be enforceable by members of the class as well as the EEOC.

Finally, limitation of the EEOC's ability to settle for future affirmative action poses a problem more apparent than real. If the future affirmative action runs to the class whose claims have been asserted-for example, changes in the seniority system benefiting an employee-class-there is no problem. If, on the other hand, the future affirmative action does not run to the class whose claims have been asserted-for example, changes in hiring practices when the EEOC has asserted the claims of an employee class-the Commission has used one class's claims as a bargaining device in obtaining relief for a different class. Not only is this unfair to the first class, who may rely to their detriment on the EEOC's assertion of their claims, it is unnecessary. Early class definition will force the EEOC to match the claims it asserts to the class for which it seeks relief.

In addition, the threat of a truly effective EEOC class suit should stimulate effective voluntary conciliation. Congress hoped that the majority of employment discrimination disputes would be handled by conciliation and voluntary compliance once the EEOC was given the power to sue. The EEOC's conciliation success rate has, however, increased only insignificantly since the 1972 amendments. ${ }^{209}$ To the extent that class certification will promote more substantial relief in EEOC class actions, employers will be more likely to agree to a voluntary settlement when the alternative is a certified class action.

${ }^{203}$ As one EEOC attorney has noted, "[d]efendants would be more likely to settle with the EEOC if the settlement could be a consent decree with a certified class representative, which would have a res judicata effect on the class." B. ScHLeI \& P. Grossman, supra note 16 , at 1107.

${ }^{200}$ See Comptroller General's REPORT, supra note 44, at 14 ("EEOC's average success rate for the six fiscal years preceding the 1972 amendments was 47.8 per cent compared to an average of 49.2 per cent for fiscal years $1973-75$, an increase of only 1.4 per cent."). 
2. Private Class Actions. Even if a requirement of EEOC class certification does have an overall negative impact on the Commission's enforcement efforts, it will still contribute to greater enforcement of the rights created by Title VII. The EEOC is not the sole enforcer of Title VII. If aggrieved individuals are not included in a certified class represented by the EEOC, their private actions on their claims will not be prejudiced by the EEOC's class suit. Since the EEOC will be required to define at the outset the class it represents, individuals will no longer be placed in the difficult position of guessing whether the EEOC is seeking relief for them or whether they ought to sue on their own before Title VII's time limitations bar the suit. Eliminating both of these problems posed by current EEOC practice-prejudice to subsequent private suits and uncertainty about the scope of the EEOC action-will ensure the vitality of the private class action, which has been a major force in Title VII enforcement. 210

3. The Judicial Role in Title VII Enforcement. Certification of EEOC class actions will enable the courts to award more complete substantive relief to aggrieved individuals. The courts have a central role in forging relief that will contribute to "the national committment to the eradication of employment discrimination."211 The courts' responsibility extends not only to the victims of past discrimination, but also to other employees who may feel the impact of either a negotiated settlement or a judicially imposed remedy. ${ }^{212}$ The heuristic function of rule 23 increases the judicial awareness of the needs and interests of both absent aggrieved individuals and other employees, enabling the court to fashion a remedy that best accomodates the sometimes inconsistent interest of these two

${ }^{210}$ See Belton, A Comparative Review of Public and Private Enforcement of Title VII of the Civil Rights Act of 1964, 31 VAND. L. Rev. 905, 961 (1978):

An assessment of the effort to enforce the national policy against discrimination that does no more than simply acknowledge that private enforcement effort has played some role in the campaign . . . is myopic . . . . The federal enforcement programs have yet to demonstrate a capacity to be as effective as their potential. Until that potential has been realized, private enforcement must be encouraged, supported, and recognized without either deliberate or unintended impediments.

$2114 \mathrm{H}$. NewBurg, supra note $52, \S 7956$, at 1223 . The Act leaves it up to the courts to fashion the appropriate relief. Act of $1972, \S 706$ (g), 42 U.S.C. $\S 2000 \mathrm{e}-5(\mathrm{~g})$ ("such affirmative action as may be appropriate which may include, but is not limited to"); Act of 1972, § 707 (a), 42 U.S.C. $\$ 2000 \mathrm{e}-6$ (a) ("such relief, including an application for a permanent or temporary injunction . . . or other order").

${ }^{212}$ See $4 \mathrm{H}$. NewBuRg, supra note 52, § 7956, at 1223 (1977) ("A judicial tribunal must frame its remedies in a manner calculated to correct past discrimination, to insure true equal employment opportunity, but must simultaneously be cognizant of the impact on other employees."). 
groups. Such an informed judicial approach serves the broad policies underlying Title VII. ${ }^{213}$

More particularly, the procedural protections afforded to absent aggrieved individuals increase the likelihood that all individuals-not just charging parties-whose rights are at issue in an EEOC class suit will have the opportunity to present their arguments to the court. Presentation of the views of all class members will not only enhance the protection of their interests but will make the class suit a more effective device for identifying and redressing discriminatory employment practices. Moreover, allowing aggrieved individuals to object to a proposed settlement will encourage involvement of class members in settlement negotiations as well as litigation. Since individuals with detailed knowledge of conditions that may not be known to the EEOC may be able to make valuable contributions, settlement negotiations involving absent class members are likely to lead to fuller enforcement of the rights protected by Title VII..$^{214}$

Most importantly, rule 23 will provide courts with a familiar procedure, designed to ensure due process in representative suits. ${ }^{215}$

${ }_{213}$ See Developments in the Law-Class Actions, supra note 149, at 1353.

214 The Civil Rights Commission has criticized the EEOC for its failure to involve minority members in settlement negotiations. Civil RIGHTS Commission REPoRT, supra note 44, at 646. The Commission recommended that the EEOC include representatives of the affected class in any negotiations for future consent decrees. Individuals with detailed knowledge of conditions of which the EEOC may not even be aware may be able to make valuable contributions to the negotiations. Id. at 671 .

${ }^{215}$ In EEOC v. General Tel. Co., 20 Fair Empl. Prac. Cas. 52 (9th Cir. 1979), the Ninth Circuit concluded that the "certification process would be time consuming and costly, and would serve no useful purpose in the final disposition of the case." Id. at 60 . In response to General Telephone's concern that it might be subjected to multiple suits and damage awards, $i d$., the Ninth Circuit pointed out that the district court could condition its award of relief on waiver of aggrieved individuals' personal rights of action. Id. Although this procedure does preclude duplicate recoveries, it does not foreclose subsequent suits, and possibly inconsistent decisions, arising out of the same employment practices. It is, in effect, a return to the pre1966 class actions in which the defendant, but not the beneficiaries of the action, were bound. See text and note at note 186 supra. Moreover, this procedure provides no protection at all for absent class members who may rely to their detriment on the EEOC's assertion of their claims. See text and notes at notes 155-164 supra. Alternatively, the Ninth Circuit suggested that the district court could order notice to "the charging party and members of the class" informing them "of the pendency of the Commission's action and their statutory right to intervene." 20 Fair Empl. Prac. Cas. at 60 . Such an order would, presumably, give defendants res judicata protection. See Restatement (Second) of Judgments, supra note 180 , $\S 88(3)$, at 90 . Yet, unless absent aggrieved individuals are given the protections of rule 23(e), they may be bound by a settlement benefiting an entirely different class. See text at notes 208209 supra. The courts have traditionally been reluctant to interfere with a settlement arranged by a coordinate branch of government. See generally Zimmer \& Sullivan, supra note 184. Thus, it is unlikely that district courts will use their equitable powers to take control of settlement and order notice of settlement sent to absent class members. The inadequacies of 
The Fifth Circuit predicted in Holmes that "[i]f EEOC is exempted from Rule 23, chaos in the management of Title VII class actions could result. Such matters as notice, exclusion, intervention, dismissal or compromise, and statute of limitations treatment would be put in question." ${ }^{216}$ Chaos has not resulted in those courts that have not applied rule 23 to EEOC suits only because they have not been aware of all these problems. ${ }^{217}$ If the courts had been sensitive to the wide variety of ways in which EEOC actions could prejudice absent aggrieved individuals and defendants, they would have been forced to develop a federal common-law procedure to deal with each of these problems. ${ }^{218}$ Application of rule 23 will ensure that the substantive rights created by Title VII are not prejudiced by the use of procedures incompatible with the full enforcement of those rights.

\section{CONCLUSION}

Since the transfer of Title VII enforcement authority to the EEOC in 1972, defendants have, with increasing frequency, challenged the propriety of the EEOC's practice of seeking classwide relief for aggrieved persons without certification under rule 23 of the Federal Rules of Civil Procedure. Although most courts considering the issue have held rule 23 inapplicable to EEOC class suits, several courts have reached the contrary conclusion. Examination of the relevant legislative history of the 1972 amendments reveals that Congress expressed no definitive view on the applicability of rule 23 to EEOC class suits. The purposes, functions, and underlying policies of both rule 23 and Title VII, however, indicate that the EEOC can meet the rule 23 requisites of a class representative and should be required to certify when it brings suit on behalf of a class of aggrieved persons. Application of rule 23 to such suits provides the

the court's two solutions belie its assertion that class certification would serve "no useful purpose." 20 Fair Empl. Prac. Cas. at 60.

216 EEOC v. D.H. Holmes Co., 556 F.2d 787, 796 (5th Cir. 1977), cert. denied, 436 U.S. 962 (1978).

217 The language used by the Ninth Circuit suggests that the court may have appreciated the need for joinder under rule 19 to protect defendants. See EEOC v. General Tel. Co., 20 Fair Empl. Prac. Cas. 52, 60 (9th Cir. 1979) ("subsequent suits on the same issues, possible double payments of damage awards, and inconsistent judicial decisions"). The court did not, however, mention any form of possible prejudice to absent class members. See id. Other courts holding the EEOC exempt from rule 23 have failed to appreciate either point. See, e.g., EEOC v. Whirpool Corp., 80 F.R.D. 10 (N.D. Ind. 1978).

${ }_{218}$ For an example of such judicial activity, see RDWSU Local 194 v. Standard Brands, Inc., 540 F.2d 864, 867 (7th Cir. 1976), in which the Seventh Circuit allowed a union to sue for injunctive relief for its members without rule 23 certification, but applied appropriate rule 23 procedures. 
procedural protections due defendant-employers and aggrieved individuals and furthers the substantive policies of Title VII.

Mary E. Becker 